\title{
On the Modeling and Development of Verb-object Construction from the Oracle Bone Inscriptions to Jinwen Shangshu
}

\author{
Ma Qinghua * \\ (Nanjing University, China) \\ Li Weizheng ${ }^{* *}$ \\ (Nanchang Normal University, China)
}

\begin{abstract}
The verb-object construction in oracle bone inscriptions is found primarily verb-object, but there is also the form of object-verb. With a mark, an object precedes its verb for the purpose of emphasis. Without a mark, the fact that an object precedes its verb is due to a relatively low level of syntactic modeling in the primitive language. The objects in oracle inscriptions having the largest scale aren't the objects acted by object arguments $\left(\mathrm{O}_{\mathrm{o}}\right)$, but additive objects $\left(\mathrm{O}_{\mathrm{a}}\right)$, which is the typical feature of object in this time. However, the object arguments had replaced the typical status of additive arguments in objects in Xizhou Chinese. The word order of double-object construction in Xizhou Chinese and Jinwen Shangshu still has the trace of a relatively low syntactic modeling level.
\end{abstract}

Keywords: oracle bone inscriptions, Xizhou bronzes inscriptions, Jinwen Shangshu, verb-object construction, modeling level, markedness level, unformedness

\section{Introduction}

The oracle bone inscriptions, which can be traced back to 3300 years ago, are the earliest unearthed documents in Chinese. In the process of modeling, the verb-object constructions in oracle bone inscriptions, limited by the conditions of language system at that time, present some obvious features in word order, type and quantity, etc. of object. From oracle bone inscriptions to inscriptions on bronzes in Xizhou (the Western Zhou Dynasty) to Jinwen Shangshu ${ }^{(1)}$, the specific situations of the modeling change to a certain extent. In

\footnotetext{
* Dr. Ma Qinghua: Professor, School of Liberal Arts, Nanjing University, Nanjing, Jiangsu, 210093, China. Fund project: The national social-sciences fund project "The research of complication problems of Chinese sentences"(11BYY084). E-mail: maqh86@nju.edu.cn.

** Dr. Li Weizheng: lecturer, College of Chinese Language and Literature, Nanchang Normal University, China. Fund project: The doctoral initial fund project of scientific research of Nanchang Normal University (NSBSJJ2015031). Email: liweizhengsr1@126.com.

(1) "Jinwen Shangshu consists of the earliest documents handed down in China, and it is the classic of political history compiled no less than 2600 or 2500 years ago. ...Most documents in Jinwen Shangshu are credible ancient texts of Shang (商) and Zhou (周) dynasties.”(Qian Zongwu, 2017)
} 


\section{Ma Qinghua \& Li Weizheng}

terms of how the modeling changes, the academic circle has made some research achievements, but they aren't intensive. The present article, whose purpose is to lead to some more intensive and valuable conclusions, states in detail from the perspectives of marked preposed objects, unmarked preposed objects, $\mathrm{O}_{\mathrm{a}} \mathrm{s}$ and features of multi-objects. The source of corpus for the article is from The Classified Compilation of Oracle bone inscriptions (Yao Xiaosui \& Xiao Ding 1989), in which all verb-object constructions are induced according to exhaustive classification, and the transcription of some individual fonts is in compliance with Xu Zhongshu (2006).

\section{The three proofs of basic word-order inclination of verb-object constructions}

The verb-object constructions in oracle bone inscriptions have both verb-object constructions and object-verb constructions, and object postposing is their basic word-order inclination, characterized by three main proofs: frequency, mark and nesting.

2.1 Frequency The verb-object constructions in oracle bone inscriptions can be classified into three categories: single object, double objects and three objects, whose order is single object $>$ double objects $>$ three objects, according to high-to-low frequency of their occurrences. In occurrence frequency, the single object occurs most frequently: of the 2849 examples in all, verb-object type has 2453 examples, followed by object-verb type, which has 396 examples in all. The double-object constructions have 210 examples in all, of which $\mathrm{VO}_{1} \mathrm{O}_{2}$ has 206 examples, $\mathrm{O}_{1} \mathrm{O}_{2} \mathrm{~V}$ has 3 examples, and $\mathrm{O}_{2} \mathrm{VO}_{1}$ has only 1 example. The three-object constructions have only one type, namely, $\mathrm{VO}_{1} \mathrm{O}_{2} \mathrm{O}_{3}$, with 12 examples in all. On the basis, it can be induced that object postposing has 2671 examples, object preposing has 399 examples, and that a verb located between two objects has 1 example. The ratio between frequency of object postposing and that of object preposing arrivals at $6.7: 1$.

2.2 Mark According to marks, the verb-object construction can be divided into two types: markedness and unmarkedness. All post-objects (include post-single object, post-double objects and post-three objects) are unmarked, and only pre-objects are marked.

In single-object constructions, object-verb constructions have 396 examples in all. Their marks can be divided into three kinds: (1) double-mark constructions "惟 ${ }_{\text {wei }} \mathrm{O}$ 其 $_{\mathrm{qi}} \mathrm{V}$ "; (2) constructions with an antecedent mark “惟 ${ }_{\text {wei }} \mathrm{OV} \mid$ 惠 $_{\text {hui }} \mathrm{OV} \mid \bigoplus_{\text {yue }} \mathrm{OV}$ ”; (3) constructions with a succedent mark " $\mathrm{O}$ 其 $_{\mathrm{qi}} \mathrm{V}\left|\mathrm{O}_{\text {惟 }} \mathrm{wei} \mathrm{V}\right| \mathrm{O}$ 于 $_{\mathrm{yu}} \mathrm{V} \mid \mathrm{O}$ 允 $_{\mathrm{yun}} \mathrm{V}$ ". Comparisons are made as follows:

【 Double-mark construction 】

$\begin{array}{cllll}\text { (1) 惟 } & \text { 嚰 } & \text { 鹿 } & \text { 其 } & \text { 擒 } \\ \text { wei } & \text { Ru } & \text { lu } & \text { qi } & \text { qin } \\ \text { OP } & \text { PIN } & \text { deer } & \text { EM } & \text { get }\end{array}$




\section{On the Modeling and Development of Verb-object Construction from} the Oracle Bone Inscriptions to Jinwen Shangshu

'to get the deer in $\mathrm{Ru}$ '

【Antecedent single-mark constructions 】

<惟OV>

(2) 惟

侯比

wei hou bi

OP chief unite

'to unite the chief'

(3) 惟师比

wei shi bi

OP army unite

'to unite the army'

<曰OV>

(4)

$\begin{array}{lll}\text { 曰 } & \text { 矤 } & \text { 至 } \\ \text { yue } & \text { Shi } & \text { zhi } \\ \text { OP } & \text { PIN } & \text { go to }\end{array}$

'to go to Shi'

<惠OV>

(5) 惠

新 丰

丰用

wei xin feng yong

EM new drum use

'to use the new drum'

(6) 惠疾以

wei Ji yi

EM PeN carry

'to carry Ji'

【 Succedent single-mark constructions 】

$\langle\mathrm{O}$ 其 $\mathrm{V}\rangle$

$\begin{array}{lll}\text { (7) 岳 } & \text { 其 } & \text { 册 } \\ \text { Yue } & \text { qi } & \text { ce } \\ \text { mountain god } & \text { EM } & \text { SN }\end{array}$

'to sacrifice the mountain god by ce'

(8) 米圆其蒸

mi Jiong qi zheng

rice $\quad$ PIN $\quad$ EM $\quad$ SN

'to sacrifice by zheng with rice in Jiong' $<\mathrm{O}$ 惟V $>$
(9) 父
旦惟
p 


\section{Ma Qinghua \& Li Weizheng}

$\begin{array}{llll}\text { Fu } & \text { dan } & \text { wei } & \text { jie } \\ \text { DN } & \text { morning } & \text { EM } & \text { SN }\end{array}$

'to sacrifice Fu by jie in the morning'

(10) $\square$ 惟处

$\mathrm{Gu}$ wei jiu

PeN EM bring evil upon

'to bring evils upon $\mathrm{Gu}$ '

$\langle\mathrm{O}$ 于 $\mathrm{V}\rangle$

(11) 父甲 木丁 于 福

Fujia Muding yu fu

DN DN $\quad$ EM $\quad$ SN

'to sacrifice Fujia and Muding by fu'

(12) 祖乙 于 寻侑

Zuyi yu xun you

DN EM SN SN

'to sacrifice Zuyi by xun and you'

$<\mathrm{O}$ 允 $\mathrm{V}>$

(13) 祖乙允飨

Zuyi yun xiang

DN exactly SN

'to sacrifice Zuyi by xiang exactly'

【Unmarked constructions 】

（14）妇好生保

Fuhao sheng bao

PeN be in childbirth bless

'to bless Fuhao to be in childbirth'

(15) 岇先 射

si xian she

rhinoceros firstly shoot

'to shoot the rhinoceros firstly'

(16) 四鹿获

si lu huo

four deer get

'to get four deer'

(17) 兹不用

zi bu yong

this not perform 


\section{On the Modeling and Development of Verb-object Construction from the Oracle Bone Inscriptions to Jinwen Shangshu}

'to perform this'

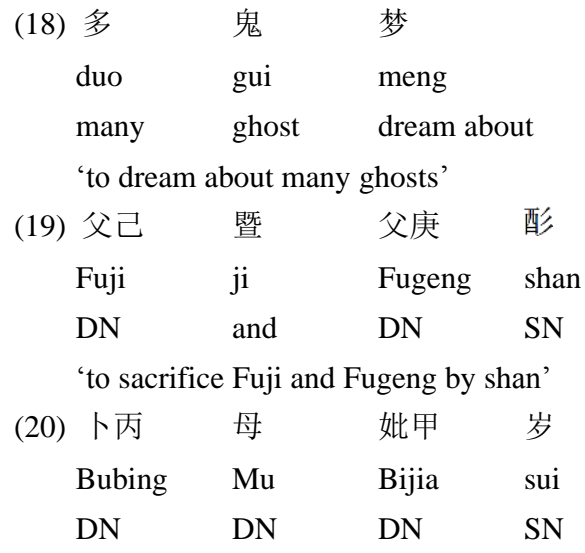

'to sacrifice Bubing, Mu and Bijia by sui'

The antecedent single-mark constructions have 216 examples, the succedent single-mark constructions have 16 examples in all, the double-mark construction has 1 example, the marked constructions have 233 examples in all, and the unmarked constructions have 163 examples. The mark scale presents the descending sequence as follows: antecedent single-mark constructions $>$ unmarked constructions $>$ succedent single-mark constructions $>$ double-mark construction. In the pre-objects, the ratio of marked ones and unmarked ones is $1.43: 1$.

The constructions of double-object preposing, namely $\mathrm{O}_{1} \mathrm{O}_{2} \mathrm{~V}$, have 3 examples in all, and only 1 example has the mark as (21).

$\begin{array}{llll}\text { (21) 曰 } & \text { 妇鼠 } & \text { 母 } & \text { 祝 } \\ \text { yue } & \text { Fushu } & \mathrm{Mu} & \text { zhu } \\ \text { OP } & \text { PeN } & \text { DN } & \text { SN }\end{array}$

'to sacrifice Mu by zhu because of Fushu'

The three-object constructions are all unmarked object-postposing constructions, such as:

$\left(\mathrm{V}, \mathrm{O}_{1}, \mathrm{O}_{2}\right.$, (attribute, head) o3)
(22) 告
蝗
上甲 二 二 牛

gao huang shangia er niu

SN grasshopper DN two cow

'to sacrifice Shangjia by gao with two cows because of the grasshoppers'

( $\mathrm{V}$, (attribute, head) ${ }_{\mathrm{O} 1}, \mathrm{O}_{2}, \mathrm{O}_{3}$ )

$\begin{array}{rllll}\text { (23) 御 } & \text { 三 } & \text { 宰 } & \text { 周 } & \text { 妣庚 } \\ \text { yu } & \text { san } & \text { yang } & \text { Zhou } & \text { Bigeng } \\ \text { SN } & \text { three } & \text { captive sheep } & \text { NN } & \text { DN }\end{array}$




\section{Ma Qinghua \& Li Weizheng}

'to sacrifice Bigeng by yu with three captive sheep because of zhou'

2.3 Nesting A declarative construction, nested by another declarative construction, is shallow nesting, whereas a declarative construction nested by a referential construction is deep nesting. In oracle bone inscriptions, the verb-object constructions can be nested either shallowly by the subject-predicate, adverbial-head and tied-predicate constructions, or deeply by attribute-head constructions. In the single objects, the verb-object constructions recursively or shallowly nested have 25 examples in all, and those deeply nested have 14 examples in all. Please note the following comparisons (The sign "( )" means the ordered sets):

【 Shallow nesting 】

<nested by the verb-object constructions (namely the verb-object recursive constructions)>

$$
\begin{array}{clll}
\left(\boldsymbol{V},\left(\left(\boldsymbol{V}, \boldsymbol{O}_{\text {dative }}\right) \mathrm{V}, \boldsymbol{O}_{\text {result }}\right)\right. & \text { o: content }) & & \\
\text { (24) 令 } & \text { 作 } & \text { 我 } & \text { 田 } \\
\text { ling } & \text { zuo } & \text { wo } & \text { zai } \\
\text { give the command } & \text { make } & \text { me } & \text { disaster }
\end{array}
$$

'to give the command to make the disaster and give this disaster to me'

$<$ nested by the subject-predicate constructions>

$\begin{array}{cllll}\left((V, V)_{V},\left(S,\left(V, O_{\text {purpose }}\right)_{P}\right)\right. & o & & \\ (25) \text { 酸 } & \text { 御 } & \text { 石甲 } & \text { 至 } & \text { 般庚 } \\ \text { shan } & \text { yu } & \text { Shijia } & \text { zhi } & \text { Pangeng } \\ \text { SN } & \text { SN } & \text { DN } & \text { to } & \text { DN }\end{array}$

\begin{tabular}{|c|c|c|c|}
\hline (26) 告 & 其 & 比 & 望乘 \\
\hline gao & qi & bi & Wangcheng \\
\hline SN & EM & unite & $\mathrm{PeN}$ \\
\hline
\end{tabular}

'to sacrifice these deities from Shijia to Pangeng by shan and yu' <nested by the adverbial-head constructions>

( $\left.\mathrm{V},\left(\text { adverbial, }\left(\mathrm{V}, \mathrm{O}_{\text {associated role }}\right)_{\text {head }}\right)_{\mathrm{o}}\right)$

\begin{tabular}{|c|c|c|c|c|}
\hline (27) 呼 & 见 & 启 & 于 & 朕 \\
\hline hu & jian & Qi & $\mathrm{yu}$ & Zhen \\
\hline give the command & meet & $\mathrm{PeN}$ & in & PIN \\
\hline
\end{tabular}

'to sacrifice by gao because of uniting Wangcheng' <nested by the head-complement constructions>

$\left(V,\left(\left(V, O_{\text {patient }}\right) v, \text { complement }\right)_{o: \text { content }}\right)$

<nested by the tied-predicate constructions>

$$
\begin{aligned}
& \left(V,\left(\left(V, O_{\text {associated role }}\right)_{V},\left(V, O_{\text {associated role }}\right)_{V}\right) \text { o: content }\right) \\
& \text { (28) 作比望乘伐危 }
\end{aligned}
$$




\section{On the Modeling and Development of Verb-object Construction from the Oracle Bone Inscriptions to Jinwen Shangshu}

$\begin{array}{lllll}\text { zuo } & \text { bi } & \text { Wangcheng } & \text { fa } & \text { Xiawei } \\ \text { do } & \text { unite } & \text { PeN } & \text { attack } & \text { NN }\end{array}$

'to do the thing of uniting Wangcheng to attack Xiawei'

【 Deep nesting 】

<nested by the attribute-head constructions $>$

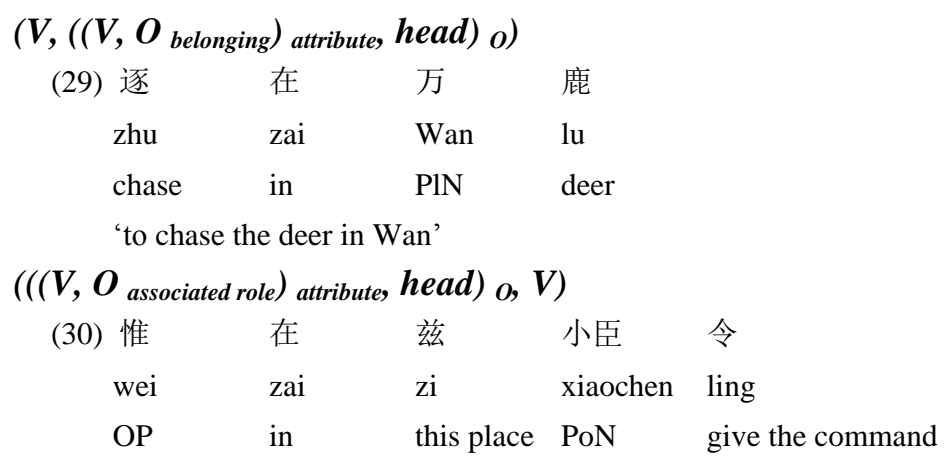

'to give the command to the xiaochen in this place'

Even when the subject arguments act as post-objects, they are also nested deeply, although the examples like this are only a few, as in:

$\begin{array}{ccccc}\left((\boldsymbol{V}, \boldsymbol{V})_{V} \text {, (attribute, }\left(\boldsymbol{V}, \boldsymbol{O}_{\text {concerned role }}\right)_{\text {head }}\right) & o \text { ) } \\ (31) \text { 祝 } & \text { 以 } & \text { 之 } & \text { 疾 } & \text { 齿 } \\ \text { zhu } & \text { yi } & \text { zhi } & \text { ji } & \text { chi } \\ \text { SN } & \text { SN } & \text { this } & \text { be ill } & \text { teeth }\end{array}$

'to sacrifice by zhu and yi because of this thing of teeth's being ill'

The object-verb construction can't be deeply nested. It can only be shallowly nested, but with only 1 example, which is the recursive construction of unmarked object-verb construction (see \$4.1). This shows that because the marked object-verb constructions carry the pragmatic information at sentence level (emphases, highlighting, moods or the temporary meanings of variable constructions, etc. in a specific context), if there's no auxiliary conditions, usually it cannot be deeply nested. ${ }^{(1)}$ The verb-object constructions are the pure syntactic constructions, the marked verb-object constructions are pragmatic-syntactic constructions, and the unmarked verb-object constructions are the performances of syntactic unformedness.

The oracle bone inscriptions establish the foundation for the basic word-order inclination

\footnotetext{
(1) Please make a comparison with the modern Chinese: 一/位/买/了/书/的/同学/对/我/说(yi/ wei/ mai/ le/ shu/ de/ tongxue/ dui/ wo/ shuo, a/ Q/ buy / PeP/ book/ AP/ student/ to/ me/ say, 'a student who has bought the book says to me') $\rightarrow$ *一/位/书/买/了/的/同学/对/我/说(yi/ wei/ shu/ mai/ le/ de/ tongxue/ dui/ wo/ shuo, a/ Q/ book/ buy/ PeP/ AP/ student/ to/ me/ say, 'a student whose book has been bought says to me').
} 


\section{Ma Qinghua \& Li Weizheng}

of Chinese verb-object constructions. From inscriptions on bronzes in Xizhou and Jinwen Shangshu to modern Chinese, the inclination is being followed all the time (Zhang Yujin, 2004:235; Qian Zongwu, 2017). The object preposing of oracle bone inscriptions ordered in different manners comes from different causes. The marked preposing is attributable to the need of emphasis; the unmarked preposing is attributable to the comparatively low level of syntactic modeling of the primitive language. They will be discussed respectively in the following sections.

\section{The causes of marked object preposing and the propagation of relevant rule system}

The marked object preposing in the oracle bone inscriptions is mainly the result of pragmatic emphases. The causes have two aspects:

A. The marked object preposing and unmarked object preposing coexist. Of the 396 examples of object-verb single-object constructions, 143 ones have the direct evidence that shows the complicated marking relation from unmarked preposing to marked preposing (please make a comparison in the following examples). The lingual force of marked preposing is obviously stronger than that of the unmarked preposing, otherwise there's no need of existence.

\begin{tabular}{|c|c|c|}
\hline (32) a & & \\
\hline Zuyi & zhu & \\
\hline DN & SN & \\
\hline 'to sac & e Zuyi b & \\
\hline b.惟 & 祖丁 & 祝 \\
\hline wei & Zuding & zhu \\
\hline $\mathrm{OP}$ & $\mathrm{DN}$ & SN \\
\hline 'to sac & e Zudins & zhu \\
\hline (33) a.衣 & 比 & \\
\hline $\mathrm{Yi}$ & bi & \\
\hline $\mathrm{PeN}$ & unite & \\
\hline 'to uni & & \\
\hline b.惟 & 侯 & 比 \\
\hline wei & hou & bi \\
\hline $\mathrm{OP}$ & chief & \\
\hline
\end{tabular}

B. The object preposing about "其q", whose formation experiences the adaptation of many links, is to take the anaphora and emphases of "其q" as the first impetus (Ma Qinghua, 2014a). The following sections will elaborate the second point in detail. 


\section{On the Modeling and Development of Verb-object Construction from the Oracle Bone Inscriptions to Jinwen Shangshu}

3.1 The pronoun nature of "其 $\mathrm{qi}$ " and the object preposing with this mark The object preposing marked by "其qi" is to take the pronoun nature of "其q" as its basis, to take the anaphora for objects as its means, and to take the effectiveness of emphasis as its purpose.

Although "其qi" is very common in oracle bone inscriptions, many scholars in the academic circle of oracle bone inscriptions usually deny the pronoun identity of “其 qi" (Li Xi, 2004:268-270; Yang Fengbin, 2003:238), or sit on the fence between acknowledging and denying, and allegedly the usage of the third person pronouns, which are parallel to and symmetric to the first person and the second person, is "not to be seen" or "seldom to be seen"; even if the usage of possessive pronouns exists, also only one example as “余/燎/ 于/其/配(yu/ liao/ yu/ qi/ pei, I/ SN/ PT/ its/ the god collocated with another god to be sacrificed together, 'I sacrifice the god collocated with it by liao')". Zhang Yujin (2001) oppugned this: "In Xizhou bronze inscriptions, pronoun “其qi” isn't seen. Could it be said that pronoun "其qi" only appears once in oracle bone inscriptions, it disappears in Xizhou, and reappears in Chunqiu (the Spring and Autumn Period) and Zhanguo (the Warring States Period)? This is irrational from the aspect of history of Chinese development."

Our opinion is that the addressing and referential functions of "其qi", which continues in modern usage, have already existed in oracle bone inscriptions.

The direct proof that "其q" has the addressing function and anaphora function for objects is that the object-preposing constructions including the double marks in oracle bone inscriptions “惟 ${ }_{\text {wei }} \mathrm{O}$ 其 $_{\mathrm{qi}} \mathrm{V}$ ” has two constructions “唯 ${ }_{\text {wei }} \mathrm{O}$ 是 ${ }_{\text {shi }} \mathrm{V} \mid$ 惟 $_{\text {wei, or 噍(wei) }} \mathrm{O}$ 之 $_{\text {zhi }} \mathrm{V}$ ”, which have the same meaning and structure in modern usage. “唯 ${ }_{\text {wei }} \mathrm{O}$ 是 ${ }_{s h i} \mathrm{~V}$ ” constructions appear seven times (Zhang Yujin, 2006:248), in which there's only one example in Xizhou bronze inscriptions (Pan Yukun, 2005:216) and four examples in Jinwen Shangshu in all, in Xizhou documents in all. In Jinwen Shangshu, “惟 wei, or or (wei) $_{\text {(wei }} \mathrm{O}$ zhi $\mathrm{V}$ ” constructions have ten examples in all.(Wang Danian, 1994; Qian Zongwu, 2017)
(34) 唯
wei 朕 禾
zhen
he
是
赏
(西周金文)
OP
my
standing grain
shi shang
repay
'to repay my standing grain'
(35) 维
wei de
德 是
OP people having the morality An
'to use the people having the morality'
shi yong
(逸周书)
用
(Yizhoushu)
(36) 惟

$\begin{array}{ll}\text { wei } & \text { yong } \\ \text { OP } & \text { a long time }\end{array}$
终
zhong
a long time
是
shi
An
图
tu
make plan
(尚书·金縢)
(Shangshu·Jinteng) 


\section{Ma Qinghua \& Li Weizheng}

'to make plans for a long time'
(37) 惟

$\begin{array}{ll}\text { 刑 } & \text { 之 } \\ \text { xing } & \text { zhishment }\end{array}$
之 恤
wei xing zhi xu zai
哉（尚书·虞书·尧典）
OP punishment An treat with caution Interj
'to treat the punishments with caution'
(38) 牝 鸡 之 晨, 惟家之索 (尚书.周书.牧誓)
pin ji zhi chen wei jia zhi suo (Shangshu.Zhoushu.Mushi)
female chicken FS crow OP family An be finished

'If the hens crow, the family must be finished.'

In the above constructions, the relation that the pronouns “是 ${ }_{\text {shi, "this, it', 之 }}$ hi, "this, it" demonstrate the pre-objects is obvious. According to the parallel principle (Zhu Dexi, 1986), it can be analogized that "其qi" has the obvious pronoun nature. From this we can see the function of "其 $q$ " in single-mark construction " $\mathrm{O}$ 其 ${ }_{\mathrm{q}} \mathrm{V}$ " obviously is also the anaphora for pre-objects. Please make a comparison between several groups of single-mark object-preposing constructions " $\mathrm{O}$ 其 ${ }_{\mathrm{qi}} \mathrm{V}$ " and “惟 ${ }_{\mathrm{wei}} \mathrm{OV}$ " having the similar semantic structures.

$\begin{array}{ccc}\text { (39) a. 父丁 } & \text { 其 } & \text { 岁 } \\ \text { Fuding } & \text { qi } & \text { sui } \\ \text { DN } & \text { An } & \text { SN } \\ \text { 'to sacrifice Fuding by sui' } \\ \text { b.惟 } & \text { 父戊 } & \text { 岁 } \\ \text { wei } & \text { Fuwu } & \text { sui } \\ \text { OP } & \text { DN } & \text { SN } \\ \text { 'to sacrifice Fuwu by sui' } \\ \text { (40) a. 母癸 } & \text { 其 } & \text { 日 } \\ \text { Mugui } & \text { qi } & \text { ri } \\ \text { DN } & \text { An } & \text { SN } \\ \text { 'to sacrifice Mugui by ri' } \\ \text { b.惟 } & \text { 上甲 } & \text { 日 } \\ \text { wei } & \text { Shangjia } & \text { ri } \\ \text { OP } & \text { DN } & \text { SN }\end{array}$

'to sacrifice Shangjia by ri'

$\begin{array}{clll}\text { (41) a. 岳 } & \text { 其 } & \text { 册 } & \text { 御 } \\ \text { Yue } & \text { qi } & \text { ce } & \text { yu } \\ \text { mountain deity } & \text { An } & \text { SN } & \text { SN }\end{array}$

'to sacrifice mountain deity by ce and yu'

b. 惟祖丁 册 


\section{On the Modeling and Development of Verb-object Construction from the Oracle Bone Inscriptions to Jinwen Shangshu}

wei Zuding ce

OP DN SN

'to sacrifice Zuding by ce'

\begin{tabular}{|c|c|c|c|}
\hline (42)a.米 & 圆 & 其 & 蒸 \\
\hline $\mathrm{mi}$ & Jiong & qi & heng \\
\hline rice & PIN & An & $\mathrm{SN}$ \\
\hline \multicolumn{4}{|c|}{ 'to sacrifice by zheng with the rice in Jiong' } \\
\hline b.惟 & 白 & 穧 & 蒸 \\
\hline wei & bai & ji & zheng \\
\hline OP & white & grain name & SN \\
\hline
\end{tabular}

'to sacrifice by zheng with white ji'

$\begin{array}{cllll}\text { (43) a.伯 } & \text { 次 } & \text { 其 } & \text { 侑 } & \text { 祝 } \\ \text { bo } & \text { Ci } & \text { qi } & \text { you } & \text { zhu } \\ \text { chief } & \text { PeN } & \text { An } & \text { SN } & \text { SN }\end{array}$

'to sacrifice by you and zhu because of chief Ci'

$\begin{array}{cll}\text { b.惟 } & \text { 戚 } & \text { 奏 } \\ \text { wei } & \text { Qi } & \text { zou } \\ \text { OP } & \text { PeN } & \text { SN }\end{array}$

'to sacrifice by zou because of Qi'

“ $\mathrm{O}$ 是 $_{\mathrm{shi}} \mathrm{V} \mid \mathrm{O}$ 之hi $_{\mathrm{zh}} \mathrm{V} \mid \mathrm{O}$ 斯 $_{\mathrm{si}} \mathrm{V}$ ” in Xizhou bronze inscriptions (or other Xizhou documents) and Shangshu and "O其 ${ }_{\mathrm{qi}} \mathrm{V}$ " in oracle bone inscriptions have the same structure, and

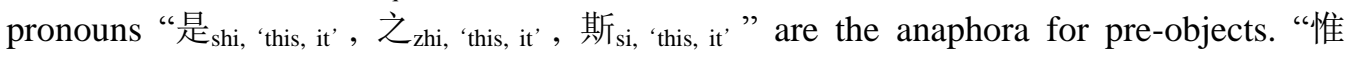
${ }_{\text {wi }} \mathrm{OV}$ " constructions at the same time and the structures of oracle bone inscriptions also come down in one continuous line. Please make a comparison:

【 The first group 】
(44) 傲 虐 nüe ao tyrannical thing 是 作
(尚书·虞夏书)
'to do the and tyrannical things'
(45) 王播告之 之修
wang bo gao zhi xiu
king proclaim An
do
zuo
(Shangshu·Yuxiashu)
'to do the things that the king proclaimed ${ }^{\text {(1) }}$
(46) 王
其
德
之用 (尚书.召诰)
wang qi de
zhi yong (Shangshu.Zhaogao)

(1) Zhou bingjun (1984:92) says: "It means to perform the things that the dead king told to do." 


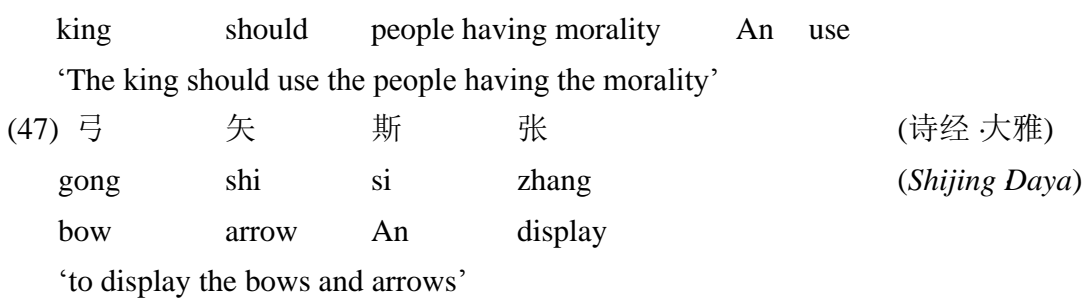

【 The second group 】

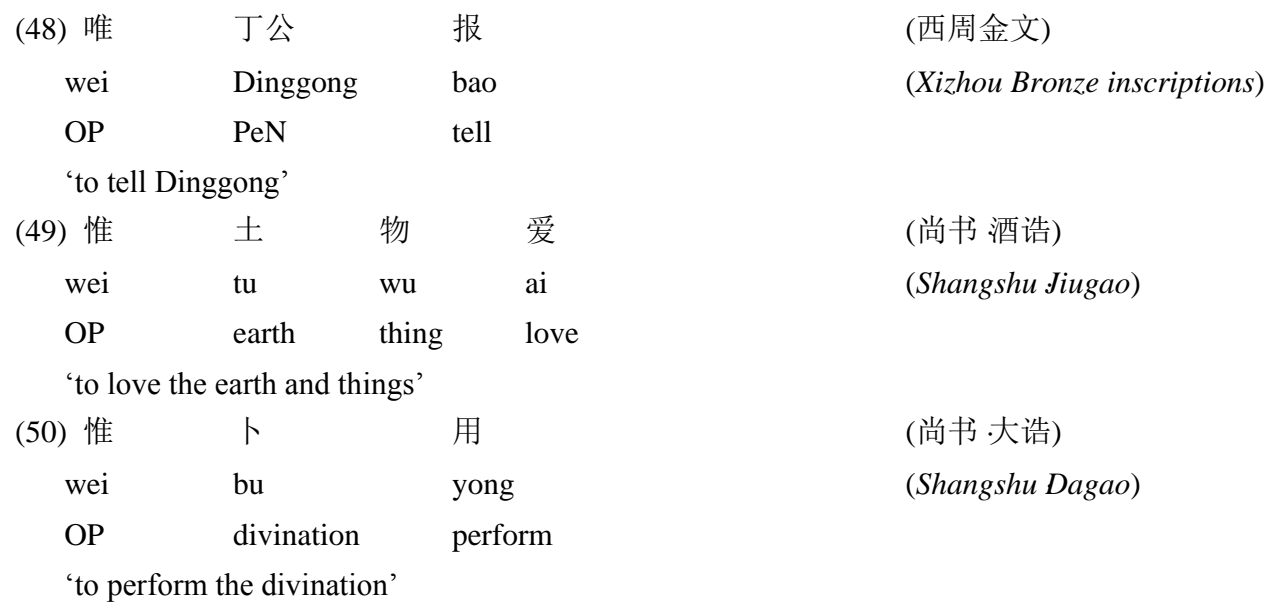

The constructions of object preposing in oracle bone inscriptions, and the constructions of object preposing in Xizhou bronze inscriptions and Jinwen Shangshu, in which marks that are used have two kinds: first, the modal marks “惟wei, 惠hui, 砛e, 于 ${ }_{y u}$, 允yun”, etc.

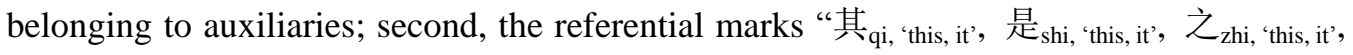
斯 si, 'this, it'” belonging to pronoun.

Frankly, the third person and the first and second person do not have the same status: (1) the first and second person are the participants of speech acts, while the third person isn't. (2) The first and second person apply more to referential pronoun in specific situations, while the third person apply more to referential pronoun in context. On the other hand, some construction relations that seem simple in modern languages, will use referential pronouns as lexical cohesion in some primitive languages whose modeling or formation-nature level is comparatively low. For example, in Nootka as a representative of polysynthetic language (the language used by Nootkas of northwest Pacific coast in North America), the first and second person have the modal marks, and the third person is the non-morphological default constructions. Even so, the empty pronoun expressing reference ?u- ("it") appears in high frequency in Nootka, to refer to or form an anaphora of the independent objects, and play a role of adherence in verb-object constructions. For example, the empty pronoun ?u- ("it") in (51) refers to ta:tna ("children")(Ma Qinghua, Fang 


\section{On the Modeling and Development of Verb-object Construction from the Oracle Bone Inscriptions to Jinwen Shangshu}

Guangzhu, Han Xiao and Zhu Hong, 2017:416-417, 432):

(51) Pu-na·k-Pa-l ta:tna (?unaak?al taatna. it-have-plural children, "They have the children.")

In oracle bone inscriptions " $\mathrm{O}$ 其 ${ }_{\mathrm{qi}} \mathrm{V}$ ", the anaphora of "其 ${ }_{\mathrm{qi}}$ " has the double of construction adherence and effects of emphases or highlighting. The pronoun "其q" uses the anaphora of pre-objects to mark the verb-object relation, which accords with the common principle of the primitive languages (the reasons can be seen above). The anaphora of "其 q" for pre-objects also meets the requirements of emphasizing effect at the same time, which accords with the iconicity principle (namely the semantic repetition is the copy that the prominent extent increases) and the principle of linguistic compensation for variant principle of redundancy (namely to offset the negative aspects of variant principle of redundancy with effect of positive emphasizing, to get the acceptability again)(Ma Qinghua, 2012:149-210).

Now let's take a look at the demonstrative function of “其q". The mood information adheres to the predicates of sentences or sentence heads. So, “其 ${ }_{q 1}$ " in " $\mathrm{V}$ 其 ${ }_{\mathrm{qi}} \mathrm{O}$ noun" in common word order, can't be the modal mark showing the mood information, and can only be the referential mark showing the referential information (the first group). Similarly, "其

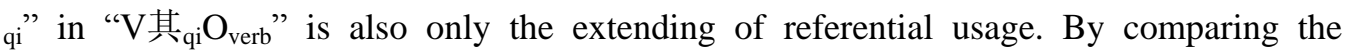
following two groups of examples in oracle bone inscriptions, it can be recognized that according to analogy, the statement term in the second group replaces the referential term in corresponding place of constructions having the same pattern, and makes the constructions complicated. This can also be understood from another aspect that a sentence of non-tiled construction usually only has a central predicate, and when other statement terms act as its object components, in oracle bone inscriptions limited by comparatively low complicating level, the nominalization appears by “其 qi” early (the second group).

【 The first group 】

\begin{tabular}{lll} 
(52) 无 & 其 & \multicolumn{1}{c}{ 灾 } \\
wu & qi & zai \\
haven't & DP & disaster \\
'to have no that disaster' \\
(53) 无 & 其 & 雨 \\
wu & qi & yu \\
haven't & DP & rain \\
'to have no that rain' & \\
(54) 丁 & 其 & 牢 \\
ding & qi & lao \\
SN & DP & captive cow
\end{tabular}

'to sacrifice by ding with these captive cows' 


\section{Ma Qinghua \& Li Weizheng}

【 The second group 】

\begin{tabular}{|c|c|c|c|c|c|}
\hline (55) 奏 & 玉 & 其 & 伐 & & \\
\hline zou & yu & qi & fa & & \\
\hline SN & jade & DP & attack & & \\
\hline 'to sc & ce by $z$ & th jade & ause of that a & king' & \\
\hline (56) 告 & 其 & 比 & 望乘 & 征 & 下危 \\
\hline gao & qi & bi & Wangcheng & zheng & Xiawei \\
\hline SN & DP & unite & $\mathrm{PeN}$ & attack & NN \\
\hline
\end{tabular}

'to sacrifice by gao because of that uniting Wangcheng to attack Xiawei'

Zhang Yujin $(2006: 167,292)$ spreads the scope of Chinese documents in Xizhou, and has the findings by conducting research again with the same judgment standard that in Xizhou Chinese the typical usage of the third person pronoun "其q", which is limited to act as the attribute components (326 examples) and subject components (49 examples), has 370 examples at least; the usage of demonstrative pronoun at least has 67 examples, which overthrows with evidence his early statement that in Xizhou bronze inscriptions pronoun "其qi" cannot be found present. From his detailed items of counted examples about pronoun "其qi" in Xizhou Chinese, it can be seen that "其q" acting as the typical usage of the third person pronoun and demonstrative pronoun in other documents of Xizhou, appears in bronze inscriptions and Shangshu, but doesn't appear in oracle bone inscriptions of Xizhou; Again, it seldom appears in bronze inscriptions and Shangshu, but usually appears in Shijing. From this it can be concluded that the frequency of typical pronoun usage of "其qi" in oracle bone inscriptions is low, which is closely related to the writing style of oracle bone inscriptions themselves and record medium. Actually, the anaphora usage of "其q" in Xizhou bronze inscriptions seldom appears. This is because that the object preposing itself is extraordinarily rare (Pan Yukun, 2005:217).

It is generally acknowledged by the academic circle that “是 ${ }_{\text {shi, “this, it" " and “之 }}$ zhi, "this, it" have the nature of pronoun and usage of object-preposing mark based on anaphora relation

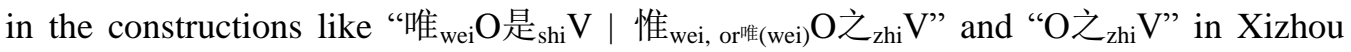
bronze inscriptions and Jinwen Shangshu (Guan Xiechu, 1981:74; Wang Danian, 1994; Qian Zongwu, 2017; Pan Yukun, 2005:216; Zhang Yujin, 2006:248). However, the academic circle of oracle bone inscriptions doesn't see the same pattern constructions “惟 ${ }_{\text {wei }} \mathrm{O}$ 其 $_{\mathrm{qi}} \mathrm{V}$ " and " $\mathrm{O}$ 其 ${ }_{\mathrm{qi}} \mathrm{V}$ " that appear earlier in this field and pronoun-nature identity and anaphora usage of "其q". It also ignores the obvious demonstrative function of "其q" in "V 其 ${ }_{\mathrm{qi}} \mathrm{O}$ noun" and the derivational usage of "其 ${ }_{\mathrm{qi}}$ " in " $\mathrm{V}$ 其 $_{\mathrm{qi}} \mathrm{O}$ verb", and only focuses on the modal meaning of "其q" which appears in high frequency, or only pays attention to the fact that "其 ${ }_{\mathrm{qi}}$ " has or hasn't the typical third person usage parallel and symmetric to the first and second person. 


\section{On the Modeling and Development of Verb-object Construction from the Oracle Bone Inscriptions to Jinwen Shangshu}

$\mathrm{Li} \mathrm{Xi} \mathrm{(2004:270)} \mathrm{argues} \mathrm{that} \mathrm{in} \mathrm{oracle} \mathrm{bone} \mathrm{inscriptions} \mathrm{"the} \mathrm{third} \mathrm{pronouns} \mathrm{aren't} \mathrm{found}$ out", but thinks that "the reason may lie in the limitedness of oracle-inscription context, and may also be likely that we have seen them but can't recognize them. Looking from the development of the first and second person pronouns and seeing them as a system, we may infer that the third person pronoun should appear in Shang". Unfortunately, this idea is only limited to mere inference.

3.2 The reanalysis and analogizing of " $\mathrm{O}$ 其 $\mathrm{qi}_{\mathrm{i}} \mathrm{V}$ " construction The boundness nature of "其 qi" leads to its close relation with the succedent predicate construction, which in turn breaks the anaphora relation between "其qi" and $\mathrm{O}$, resulting in the reanalysis of " $\mathrm{O}$ 其 $\mathrm{qi}$ " construction (" $\mathrm{O}$ 其 $_{\mathrm{q} i} / \mathrm{V} \rightarrow \mathrm{O} /$ 其 $_{\mathrm{qi}} \mathrm{V}$ "). The formal proof is that negative words can only be used before "其q", and thus "其qi" enters the domains of negative words, forming the " $\mathrm{O} /$ 不 ${ }_{\text {bu }}$ 其 $_{\mathrm{q}} \mathrm{V}$ ” construction. For example:

$\begin{array}{ccccc}\text { (57) II } & \text { 豕 } & \text { 不 } & \text { 其 } & \text { 擒 } \\ \text { Er } & \text { shi } & \text { bu } & \text { qi } & \text { qin } \\ \text { PIN } & \text { pig } & \text { not } & \text { An } & \text { get }\end{array}$

$$
\text { 'not to get the pigs in Er' }
$$

$\begin{array}{llll}\text { (58) 蝗 } & \text { 不 } & \text { 其 } & \text { 御 } \\ \text { huang } & \text { bu } & \text { qi } & \text { yu } \\ \text { grasshopper } & \text { not } & \text { An } & \text { SN }\end{array}$

'not to sacrifice by yu because of grasshoppers'

Because VO is the prominent word order in oracle bone inscriptions, "其 ${ }_{\mathrm{q}}$ " in " $\mathrm{O}$ 其 $_{\mathrm{q}} \mathrm{i}$ " is the anaphora of $\mathrm{O}$, meanwhile also refers back to the traces left in former positions after

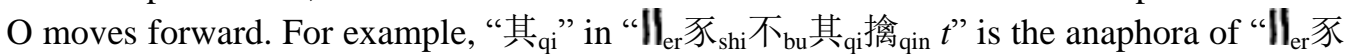
shi", and also refers back to t. However, in " $\mathrm{O}$ 不 ${ }_{b u}{ }_{\text {其 }}{ }_{\mathrm{qi}} \mathrm{V}$ " construction representing the achievement of reanalyzing " $\mathrm{O}$ 其 $_{\mathrm{qi}} \mathrm{V}$ ", the referring-back relation of "其 ${ }_{\mathrm{qi}}$ " becomes the only move-refer relation, namely the function-distribute pattern "negative word + pronoun + transitive verb $+\mathrm{t}$ ", on which by analogy, in oracle bone inscriptions there's the new important grammatical principle: Pronoun objects need the preposing in negative sentences. In oracle bone inscriptions, the object postposing is usual, but in negative sentences, pronouns like “我(wo, 'I, me'), 余(yu, 'I, me'), 尔(er,'you')”, etc., acting as the objects are usually preposed, and rarely postposed (Zhang Yujin, 2001:148), and thus forming a special construction. Here are the examples of the preposed pronouns (59a), and postposed pronouns $(59 \mathrm{~b})$. Please make a comparison:

$$
\begin{aligned}
& \text { (59) a. 贞: 祖辛丕 我 害? 贞: 祖辛害 我? } \\
& \text { zhen Zuxin bu wo hai zhen Zuxin hai wo } \\
& \text { ask DN not me take disaster to ask DN take disaster to me }
\end{aligned}
$$

'ask: Doesn't Zuxin take disasters to me? ask: Does Zuxin take disasters to me?' 
Ma Qinghua \& Li Weizheng

$\begin{array}{clllllll}\text { b. } \begin{array}{l}\text { 家 } \\ \text { w }\end{array} & \text { 旧 } & \text { 老 } & \text { 臣 } & \text { 亡 } & \text { 害 } & \text { 我 } \\ \text { wo } & \text { jia } & \text { jiu } & \text { lao } & \text { chen } & \text { wu } & \text { hai } & \text { wo } \\ \text { my } & \text { family } & \text { old } & \text { old } & \text { minister } & \text { not } & \text { take disaster to } & \text { me }\end{array}$

'My old minister doesn't take disasters to me.'

This construction, in which the pronouns are used after negative words, is followed in Xizhou Chinese and Shangshu, and modeling level is enhanced in development, which shows in: (1) the scope of appropriate pronouns spreads; (2) the principle is stricter. "In oracle bone inscriptions, the interrogative pronouns aren't found" (Shi Cunzhi, 1986:121). The sentence patterns in which interrogative pronouns act as the pre-objects aren't found in Xizhou bronze inscriptions (Guan Xiechu, 1981:75). In Jinwen Shangshu interrogative pronouns acting as the objects has 11 examples, which are all located before verb predicates without exceptions, and mostly appear in Zhoushu; the earliest examples appear in Gaoyaomo of Yuxiashu, and this may be the source of such sentence patterns in written languages (Wang Danian, 1994; Qian Zongwu, 2017).

3.3 The attainment of modal meaning of “其 qi" After “其 qi" fully realizes the value of referential meaning to form three phenomena of object preposing (the anaphora and emphasis of pre-objects, reanalysis of constructions and preposing of pronoun objects in negative sentences), " $\mathrm{O}$ 其 $_{\mathrm{qi}} \mathrm{V}$ " construction has the second reanalysis; “其q" ignores the movement-anaphoric relation, and develops directly the syntactic-semantic relation with verbs. Semantically, it moves towards the subjectivity of the modal meaning relating to verbs, but the kinds of modal meaning derived and their deriving traces are regulated by its basic pronoun nature of “其qi”, so it's partly equivalent to the modal meaning of “惟wei, 惠

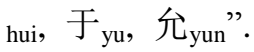

Ignoring the pronoun nature of "其 $q$ " " leads to the trouble in finding out the source of the corresponding modal meaning of “其qi". It is a common phenomenon in language that modal marks develops from referential marks, rather than the reverse. The typical referential marks refer to the concrete things; when they vaguely refer to the abstract modalities, they naturally get the modal meaning, such as “她/这么//那么/说/了(ta/ zheme// name/ shuo/ le, she/ like this// like that/ say/ PeP, 'she has said like this/like that') $\rightarrow$ 她/这么//那么/热情(ta/ zheme/ name/ reqing, she/ like this// like that/ enthusiastic, 'she's so enthusiastic')". "So" in English is also like this, such as "think so referential mark $\rightarrow$ so modal mark beautiful”. It is also true with Japanese, as in “そんなこと(like that/ thing, "the thing like that') そんなにすくない (so/ little, 'so little')". The reversal hypothesis of its development, namely, the hypothesis that modal marks develop into referential marks, is short of the support of evidence.

In oracle bone inscriptions, the modal meaning of "其qi" is functioned as "imperative" mood or the meaning of future tense "will", and it also expresses "inference" and 


\section{On the Modeling and Development of Verb-object Construction from the Oracle Bone Inscriptions to Jinwen Shangshu}

"rhetorical question" in pre-Qin (Zhang Yujin, 2001). If they are linked to the meanings of the pronoun, the similar relevant semantic-deriving relation is also able to be seen in other languages. Please make a comparison among poly-semantic relations:

Indo-European language family-【German】es (1. he, she and it; 2. (used in contexts) this and that; 3. expressing the feelings or surrounding environments; 4. acting as the formal subjects to make moods enhanced or vivid)【French】 ce (1. this/that; 2. used in interrogative sentences; 3 . Acting as the formal subjects in front of sentence heads or in back of nouns to express the emphasis); tel (1. such and this kind of; 2. expressing the purposes). Austronesian language family-【Woleaian, located in Caroline Islands of the eastern Pacific Ocean】 $p w a$ (1. that and it; 2. for); be (1. that and it; 2. wanting to do something, will do something, must do something and may do something. Please make a comparison with "me" (this, here and this thing), which has the inner alternate relation with it) (Sohn \& Tawerilmang, 1976).

In relation of morphological extension, from words having the meaning of referential pronoun to words having the "imperative/will" meaning, the morphology shows the complexity. Conversely, it shows the simplification without exceptions. This formally shows that the pronoun meaning is the formative foundation of "imperative" meaning or "will" meaning. Please make a comparison:

Indo-European language family-【German】der, die, das (1. this; 2. he, she, it and they; 3. relative pronoun, 4 . used in nominalization of any word classes) $\rightarrow$ dereinst (future and afterwards)【French】 $i l$ (he/it (act as the subjects)) $\rightarrow$ illusion (fantasy, dream and delusion). Altaic language family-【Japanese】あれ (1. that, there and that time; 2. that people and that thing) $\rightarrow$ れかし (hope and yearn). Austronesian language family-【Mokilese (one of Micronesian languages)】 mehkij/mehkos (something) $\rightarrow$ mehkihla(admire)(Harrison \& Albert, 1977).

The statement above takes the anaphora of "其 ${ }_{\mathrm{q}}$ " as starting point to illustrate the source of emphasizing meaning of "O其 ${ }_{\mathrm{q}} \mathrm{V}$ " construction, the source of word order of “不 ${ }_{\mathrm{bu}}$ 其 $_{\mathrm{qi}}$ " in "O不 ${ }_{\mathrm{bu}}$ 其 $_{\mathrm{qi}} \mathrm{V}$ ", the source of object preposing of personal pronouns in negative sentences, and the source of modal meaning of "其 ${ }_{\mathrm{q}}$ " before predicates. These syntactic or semantic achievements in different links are all superposed in the same synchronic plane.

\section{The cause of unmarked object preposing: the low modeling level}

When the object arguments (including patients, copulative roles and dative roles being to head arguments) or additive arguments (namely non-head arguments) in semantics (Ma Qinghua, 2006:248) are unmarkedly preposed, should they be looked on as objects or thematic subjects? There are different views on this in the academic circle, especially when they are located before negative words, for example: 


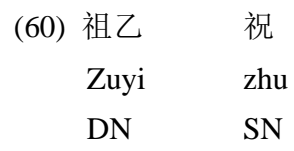

'to sacrifice Zuyi by zhu'

(61) 兹不 用

zi bu yong

this action not perform

'not to perform this action'

If observing from historical perspective, and taking into account the following reasons, we are unable to exclude their nature of pre-objects, which to some extent reflects the construction unsetting nature in primitive languages and their comparatively low level of syntactic modeling.

4.1 The nested function An unmarked object-verb construction can be nested shallowly by another verb-object construction in a recursive manner, such as the following example:

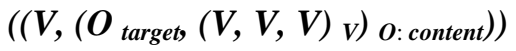

$\begin{array}{lllll}\text { (62) 为 } & \text { 祖丁 } & \text { 协 } & \text { 衣 } & \text { 划 } \\ \text { wei } & \text { Zuding } & \text { xie } & \text { yi } & \text { ge } \\ \text { perform } & \text { DN } & \text { SN } & \text { SN } & \text { SN }\end{array}$

'to sacrifice Zuding by xie, yi and ge'

If it's wrapped by the thematic subject of the pragmatic information at the sentence level, it's usually very difficult to be shallowly nested by verbs except for the psychological and speech verbs, to say nothing of being able be deeply nested, because the nesting will filtrate its pragmatic information at the sentence level, but the thematic subjects don't allow this information to be filtrated, and therefore, they are never compatible. The reorganization function of untypical word orders (including the function of inner extension and entering the bigger constructions) generally is lower than that of typical word orders. This is also the reason that object-verb constructions can't be deeply nested like verb-object constructions.

4.2 The general background of modeling level of word orders The low modeling level of word orders is the general background characterized by the syntactic features in oracle bone inscriptions.

A. In single-object constructions, the unmarked preposing of objects is an unusual kind of word orders, but there're comparatively many exceptions. Please make a comparison (" \{\}$"$ expresses the unordered sets, the same below):

$\left\lceil\mathrm{O}_{\mathrm{o}}\right\rfloor$

$$
\left\{\boldsymbol{V}, \boldsymbol{O}_{\text {patient }}\right\}
$$
(63) 狩
麇 


\section{On the Modeling and Development of Verb-object Construction from the Oracle Bone Inscriptions to Jinwen Shangshu}

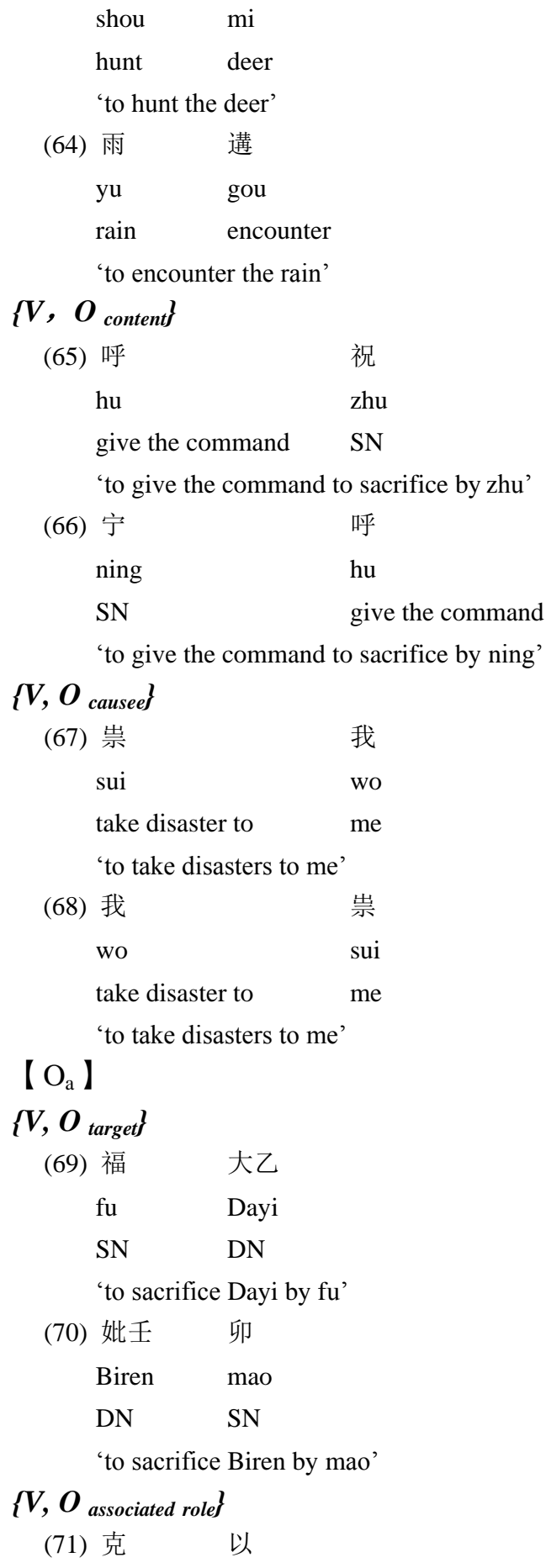

$\left\lfloor\mathrm{O}_{\mathrm{a}}\right\rfloor$

$\left\{\boldsymbol{V}, \boldsymbol{O}_{\text {target }}\right\}$

(69) 福 大乙

fu Dayi

SN DN

'to sacrifice Dayi by fu'

(70) 妣壬卯

Biren mao

DN SN

'to sacrifice Biren by mao'

$\{\boldsymbol{V}, \boldsymbol{O}$ associated role $\}$
(71) 克
以 


\section{Ma Qinghua \& Li Weizheng}

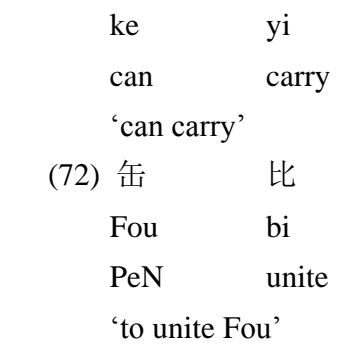

$\left\{\mathrm{V}, \boldsymbol{O}_{\text {place }}\right\}$

(73) 屎有田

shi you tian

fertilize prefix farmland

'to fertilize the farmland'

(74) 惟门田

wei Men tian

OP PIN hunt

'to hunt in Men'

$\left\{\boldsymbol{V}, \boldsymbol{O}_{\text {destination }}\right\}$

(75) 入 㒸

ru Qiang

enter $\quad \mathrm{NN}$

'to enter Qiang'

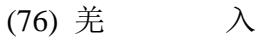

Qiang ru

NN enter

'to enter Qiang'

$\left\{\boldsymbol{V}, \boldsymbol{O}_{\text {tool }}\right\}$

(77) 祝牛

zhu niu

SN cow

'to sacrifice by zhu with cows'

(78) 羊祝

yang zhu

goat SN

'to sacrifice by zhu with goats'

$\left\{\boldsymbol{V}, \mathrm{O}_{\text {purpose/cause }}\right\}$

(79) 御妇好

yu Fuhao 


\section{On the Modeling and Development of Verb-object Construction from the Oracle Bone Inscriptions to Jinwen Shangshu}

SN PeN

'to sacrifice by yu because of Fuhao'

(80) 宣方燎

Xuanfang liao

NN SN

'to sacrifice by liao because of Xuanfang, ${ }^{1}$

In double-object constructions or three-object constructions, the word orders among several objects are comparatively free. Please make a comparison among following examples.

【The first group】

a. $\left(V,\left\{O_{\text {target }}, \boldsymbol{O}_{\text {tool }}\right\}\right)$

$\begin{array}{rll}\text { (81) 祝 } & \text { 大乙 } & \text { 牛 } \\ \text { zhu } & \text { Dayi } & \text { niu } \\ \text { SN } & \text { DN } & \text { cow }\end{array}$

'to sacrifice Dayi by zhu with cows'

$\begin{array}{rll}\text { (82) 止 } & \text { 豕 } & \text { 妣 } \\ \text { zhi } & \text { shi } & \text { Bi } \\ \text { SN } & \text { pig } & \text { DN }\end{array}$

'To sacrifice Bi by zhi with pigs'

b. $\left(\boldsymbol{V},\left\{\boldsymbol{O}_{\text {purpose/cause, }} \boldsymbol{O}_{\text {place }}\right\}\right)$

(83) 示兔鄙

shi $\quad \mathrm{Tu} \quad$ bi

SN PeN border

'to sacrifice by shi because of Tu in border'

$\begin{array}{cll}\text { (84) 御 } & \text { 家 } & \text { 艰 } \\ \mathrm{yu} & \text { jia } & \text { jian } \\ \mathrm{SN} & \text { ancestral temple } & \text { disaster }\end{array}$

'to sacrifice by yu because of disaster in ancestral temple'

c. $\left(V,\left\{O_{\text {target }}, O_{\text {place }}\right\}\right)$
(85) 祝
父丁
必
zhu Fuding bi
SN DN ancestral temple

\footnotetext{
(1) Only the object components acted by subject arguments $\left(\mathrm{O}_{\mathrm{s}}\right)$ only have the verb-object constructions and haven't the object-verb constructions. For example: ( $\mathrm{V}, \mathrm{O}_{\text {agent }}$ ) 来 lai, 'appear'雨 yu, 'rain' ('the rain

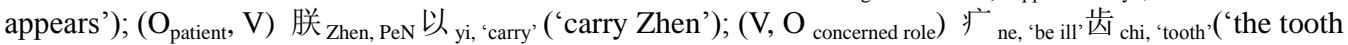
are ill'). The subject arguments before verbs only act as the subject components, which shows that the subject arguments and object arguments are asymmetrical when the syntax forms.
} 


\section{Ma Qinghua \& Li Weizheng}

'to sacrifice Fuding by zhu in ancestral temple'

(86) 奏㟧日南

zou shan ri nan

SN hill sun god south god

'to sacrifice sun god and south god by zou in hill'

d. $\left(V,\left\{O_{\text {purpose/cause, }} O_{\text {target }}\right\}\right)$

(87) 御雀父乙

yu Que Fuyi

SN PeN DN

'to sacrifice Fuyi by yu because of Que'

(88) 曰妇鼠 母 祝

yue Fushu $\mathrm{Mu}$ zhu

OP PeN DN SN

'to sacrifice Mu by zhu because of Fushu'

e. $\left(V,\left\{O_{\text {purpose/cause, }} \boldsymbol{O}_{\text {tool }}\right\}\right)$

(89) 御家

yu Ziyang shi

SN PeN pig

'to sacrifice by yu with pigs because of Ziyang'

(90) 奏 玉 其 伐

zou yu qi fa

SN jade EM attack

'to sacrifice by zou with jades because of attack'

(91)人牛人

ren niu shan

people cow SN

'to sacrifice by shan with cows because of some people'

【The second group \

$\left(\boldsymbol{V},\left\{\boldsymbol{O}_{\text {purpose/cause }}, \boldsymbol{O}_{\text {target }}, \boldsymbol{O}_{\text {tool }}\right\}\right)$

(92) 寧 风 北巫 犬

ning feng Beiwu quan

SN wind blowing DN dog

'to sacrifice Beiwu by ning with dogs because of wind blowing'

(93) 卯 犬 庚

mao quan zi Geng

SN dog child DN

'to sacrifice Geng by mao with dogs because of children' 


\section{On the Modeling and Development of Verb-object Construction from the Oracle Bone Inscriptions to Jinwen Shangshu}

In the uncommon word orders of double-object constructions, the objects can be located before verbs and after verbs simultaneously, or can be both located before verbs. But examples of this kind are only a few. For example:

\begin{tabular}{|c|c|c|c|c|c|}
\hline \multicolumn{6}{|c|}{$\left(O_{\text {purpose/cause, }}, O_{\text {target }}, V\right)$} \\
\hline \multirow[t]{3}{*}{ (94) } & 曰 & 妇鼠 & 母 & 祝 & \\
\hline & yue & Fushu & $\mathrm{Mu}$ & zhu & \\
\hline & $\mathrm{OP}$ & $\mathrm{PeN}$ & DN & $\mathrm{SN}$ & \\
\hline \multicolumn{6}{|c|}{ 'to sacrifice Mu by zhu because of Fushu' } \\
\hline \multicolumn{6}{|c|}{$\left(O_{\text {associated role }}, V_{\text {including patient }}, O t_{\text {dative }}\right)$} \\
\hline \multicolumn{2}{|c|}{ (95) 我 } & \multicolumn{2}{|l|}{ 穑 } & \multicolumn{2}{|l|}{ 旅 } \\
\hline & wo & \multicolumn{2}{|l|}{ se } & \multicolumn{2}{|l|}{ lü } \\
\hline & me & \multicolumn{2}{|c|}{ provide the foodstuffs } & \multicolumn{2}{|l|}{ army } \\
\hline \multicolumn{6}{|c|}{ 'to provide the foodstuffs to the army for me' } \\
\hline \multicolumn{6}{|c|}{$\left(O_{\text {purpose/cause }}, \boldsymbol{V}, \boldsymbol{O}_{\text {content }}\right)$} \\
\hline \multirow[t]{3}{*}{$(96)$} & 惟 & 占方 & \multicolumn{2}{|l|}{ 呼 } & 御 \\
\hline & wei & Gongfang & \multicolumn{2}{|l|}{ hu } & yu \\
\hline & $\mathrm{OP}$ & $\mathrm{NN}$ & \multicolumn{3}{|c|}{ give the command } \\
\hline
\end{tabular}

'to give the command to sacrifice by yu because of Gongfang'

B. The modeling level of attribute-head constructions in interior object can act as the powerful circumstantial evidence that the lingual structures of oracle bone inscriptions has the non-stereotyped nature. The attribute-head constructions and head-attribute constructions are both seen in extended-once constructions of objects, but the former is far more than the latter. The percentage of head-attribute constructions acting as the objects is low in verb-object constructions, and the percentage of it acting as the objects is very low in object-verb constructions, only $1.72 \%$.

Table 1. The statistical table of verb-object constructions that objects in oracle bone inscriptions are the attribute-head constructions

\begin{tabular}{|c|c|c|c|c|c|c|c|c||}
\hline \hline \multirow{2}{*}{ constructions } & \multicolumn{2}{|c|}{$\mathrm{O}=$ attribute-head constructions } & \multicolumn{2}{|c|}{$\mathrm{O}=$ head-attribute constructions } & \multicolumn{2}{|c|}{ total } \\
\cline { 2 - 9 } & $\begin{array}{c}\text { typical } \\
\text { number }\end{array}$ & $\begin{array}{c}\text { quantity of } \\
\text { examples }\end{array}$ & ratio \% & $\begin{array}{c}\text { typical } \\
\text { number }\end{array}$ & $\begin{array}{c}\text { quantity of } \\
\text { examples }\end{array}$ & ratio \% & $\begin{array}{c}\text { quantity of } \\
\text { examples }\end{array}$ & ratio \% \\
\hline $\mathrm{V}-\mathrm{O}$ & $\mathrm{A}_{1}$ type & 382 & 88.22 & $\mathrm{~B}_{1}$ type & 51 & 11.78 & 433 & 88.19 \\
\hline $\mathrm{O}-\mathrm{V}$ & $\mathrm{A}_{2}$ type & 57 & 98.28 & $\mathrm{~B}_{2}$ type & 1 & 1.72 & 58 & 11.81 \\
\hline total & & 439 & 89.41 & & 52 & 10.59 & 491 & $100 \%$ \\
\hline
\end{tabular}

The interdependent distances are in proportion to the complex degrees of sentences. The longer the interdependent distances of components in sentences are, the higher the cost of construction integration and storage cost will be. Therefore, it needs to spend more energy 


\section{Ma Qinghua \& Li Weizheng}

in handling them, and the syntactic complexity also increases accordingly. Please use an example to see how to calculate the average interdependent distance of "John read the book quickly". Mark every word according to word order first, namely: John-1 read-2 the-3 book-4 quickly-5. The distance of independent relations is the absolute value of sequential minus. In this sentence, the distances of every independent relations are: (1) 1 (read-2, John-1); (2) 1 (book-4, the-3); (3) 2 (read-2, book-4); (4) 3 (read-2, quickly-5). The average interdependent distance of a sentence is the independent quantity that the sum of all interdependent distances in sentences is divided by sentences. The interdependent distance of the above sentence is $7 / 4=1.75$. Please make a comparison between average interdependent distance of following 4 examples, and the marker words in brackets ( ) temporarily don't need to be disregarded, so the word quantity of 4 examples is the same.

\begin{tabular}{|c|c|c|c|c|}
\hline \multirow{4}{*}{ (97) a. $\left[\mathrm{A}_{1}\right.$ type $]$} & & & \multirow{2}{*}{\multicolumn{2}{|c|}{ 豕 }} \\
\hline & 获 & 八 & & \\
\hline & huo & ba & \multicolumn{2}{|l|}{ shi } \\
\hline & get & eight & \multicolumn{2}{|l|}{ pig } \\
\hline \multicolumn{5}{|c|}{ 'to get the eight pigs' } \\
\hline \multirow[t]{4}{*}{$\mathrm{B}_{1}$ type } & 获 & 狐 & \multicolumn{2}{|l|}{ 九 } \\
\hline & huo & hu & \multicolumn{2}{|l|}{ jiu } \\
\hline & get & fox & \multicolumn{2}{|l|}{ nine } \\
\hline & \multicolumn{4}{|c|}{ 'to get the nine foxes' } \\
\hline \multirow[t]{4}{*}{ (98) a. } & (惟) & 犬 & 师 & 比 \\
\hline & wei & Quan & shi & bi \\
\hline & EM & $\mathrm{NN}$ & army & unite \\
\hline & 'to un & the arn & f Quan & \\
\hline \multirow[t]{3}{*}{ b. $\left[\mathrm{B}_{2}\right.$ type $]$} & 米 & 谷 & (其) & 蒸 \\
\hline & $\mathrm{mi}$ & Jiong & qi & zheng \\
\hline & rice & PIN & EM & $\mathrm{SN}$ \\
\hline
\end{tabular}

Under the premise of the same word quantities, the average interdependent distance of $B_{1}$ type is nearer than that of $A_{1}$ type. For example, the average interdependent distance of example (91a) is 1.5 , and the average interdependent distance of example (91b) is 1 . This show that when attribute-head constructions act as objects, they violate the usual attribute-head word order, and the one of motive forces of changing to adopt head-attribute word order is to temporarily decrease the complexity. On the other hand, the average interdependent distance of $\mathrm{B}_{2}$ type is farer than that of $\mathrm{A}_{2}$ type. For example, the average interdependent distance of example (92a) is 1 , and the average interdependent distance of example (92b) is 1.5. This shows that $\mathrm{B}_{2}$ type violates the usual word order of attribute-head constructions, and increases the interdependent distance and syntactic 


\section{On the Modeling and Development of Verb-object Construction from the Oracle Bone Inscriptions to Jinwen Shangshu}

complexity, which is equivalent to paying the double price. Just because of this, its occurrence frequency is very low, and perhaps it can be only seen in emphatic expresses of marked preposing (such as example (92b)).

To temporarily get some benefit outside expressing effects, such as benefit in economic efficiency, oracle bone inscriptions can easily get rid of the constraint of syntactic pattern (such as example (91b)) to show the comparatively low modeling level and non-stereotype nature of the constructions. The increase of modeling levels in modern Chinese further verifies the judgement of non-stereotype nature of syntactic constructions in oracle bone inscriptions. In negative sentences of oracle bone inscriptions, that pronoun objects are preposed as usual (see §3.2), and in Xizhou Chinese and Shangshu this phenomenon still exists (Zhang Yujin, 2004:326-327; Qian Zongwu, 2004:426). The Shangshu also use “惟 wei" to prepose objects, and that nominal objects are preposed without "惟wei" is an exception which is comparatively scarce. By synthesizing many scholars' researches, Wang Danian (1994) holds that this nominal object preposing and pronoun object preposing in negative sentences like “惟 ${ }_{\text {wei }} \mathrm{O}$ 是 ${ }_{\text {shi, or之(zhi) }} \mathrm{V}$ ” had disappeared in spoken languages in Han Dynasty. These all show the increase of level of construction modeling.

C. The extension situation of objects in oracle bone inscriptions also reflects that the level of syntactic deep organization is low, which is in relation to the low level of syntactic modeling. In single-object constructions of oracle bone inscriptions, the non-extended constructions of objects are in the majority. The frequency of extended constructions and extension quantity of times are in negative correlation, namely the more the extension quantity of times are, the less the frequencies will be. Please make a comparison in following table:

Table 2. The statistical table of extension scale of objects in oracle bone inscriptions

\begin{tabular}{|c|c|c|c|c|c|c|c|c|c|c|c|c|}
\hline \multirow{3}{*}{$\begin{array}{c}\text { syntactic- } \\
\text { semantical } \\
\text { constructions }\end{array}$} & \multicolumn{2}{|c|}{$\begin{array}{c}\text { non-extended } \\
\text { constructions of objects }\end{array}$} & \multicolumn{9}{|c|}{ extended constructions of objects } & \\
\hline & \multirow{2}{*}{$\begin{array}{l}\text { quantity of } \\
\text { examples }\end{array}$} & \multirow{2}{*}{ ratio $\%$} & \multicolumn{7}{|c|}{ extended times } & \multirow{2}{*}{$\begin{array}{l}\text { quantity of } \\
\text { examples }\end{array}$} & \multirow{2}{*}{ ratio \% } & \\
\hline & & & once & twice & thrice & four & five & six & nine & & & \\
\hline $\mathrm{V}, \mathrm{O}_{\mathrm{o}}$ & 541 & 64.79 & 227 & 41 & 15 & 9 & 0 & 1 & 1 & 294 & 35.21 & 835 \\
\hline $\mathrm{V}, \mathrm{O}_{\mathrm{a}}$ & 1077 & 68.64 & 365 & 74 & 35 & 14 & 3 & 1 & 0 & 492 & 31.36 & 1569 \\
\hline $\mathrm{V}, \mathrm{O}_{\mathrm{s}}$ & 47 & 95.92 & 2 & 0 & 0 & 0 & 0 & 0 & 0 & 2 & 4.08 & 49 \\
\hline $\mathrm{O}_{0}, \mathrm{~V}$ & 89 & 53.94 & 64 & 10 & 2 & 0 & 0 & 0 & 0 & 76 & 46.06 & 165 \\
\hline $\mathrm{O}_{\mathrm{a}}, \mathrm{V}$ & 196 & 84.85 & 29 & 4 & 2 & 0 & 0 & 0 & 0 & 35 & 15.15 & 231 \\
\hline total & 1950 & 68.45 & 687 & 129 & 54 & 23 & 3 & 2 & 1 & 889 & 31.55 & 2840 \\
\hline
\end{tabular}

\section{The typical status of $\mathrm{O}_{a}$ s and poly-objects}




\section{Ma Qinghua \& Li Weizheng}

In common mature languages (such as modern Chinese, etc.), the typical mapping relation in time that the semantic constructions become syntactic constructions is that must-have arguments (namely compulsive arguments, including subject arguments and object arguments) become the syntactic central components, in which the subject arguments (including agent and concerned role, etc.) become the subject components, and the object arguments [including the patient, copulative role, result, content, concerned role, dative and causative, etc.] become the object components. On the other hand, the optional arguments [namely the additive arguments, including place, time, direction, ablative, allative (expressing the directions of motorial spaces, namely moving to certain places), orientation (expressing the facing directions of existence spaces), tool, comitative, associated role, cause and purpose, etc.] become the syntactic additive components (namely the adverbials or complements). This mapping relation accords with the similarity principle. (Ma Qinghua, 1993; Ma Qinghua, 2014b; Ma Qinghua, Fang Guangzhu, Han Xiao and Zhu Hong, 2017:44, 163, 462)

However, because of the reasons including the ways of function words are absent due to the low grammaticalization level, etc., the oracle bone inscriptions show the obvious different situations. The object components acted by object arguments, subject arguments and additive arguments. The objects in oracle inscriptions having the largest scale aren't the $\mathrm{O}_{0} \mathrm{~s}$, but $\mathrm{O}_{\mathrm{a}} \mathrm{s}$, namely the objects acted by optional arguments ${ }^{\mathbb{1}}$, which is the typical feature of objects in that time. The verb-object constructions in modern Chinese mainly express the relation of "action-object", the $\mathrm{O}_{\mathrm{a}} \mathrm{s}$ are all only seen in the constructions having the comparatively low analogical functions (such as “吃/食堂(chi/ shitang, eat/ canteen, 'eat in the canteen') | 吃/大/碗(chi/ da/ wan, eat/ big/ bowl, “eat with the big bowl')"). In the verb-object constructions of single-object constructions in the oracle bone inscriptions, the examples of $\mathrm{O}_{\mathrm{a}}$ (1569 examples) are the most in number, followed by examples of $\mathrm{O}_{\mathrm{o}}(835$ examples), with the examples of $\mathrm{O}_{\mathrm{s}}$ the fewest (49 examples). In the object-verb constructions of single-object constructions in the oracle bone inscriptions, the examples of $\mathrm{O}_{\mathrm{a}}$ (231 examples) are the largest in number; the examples of $\mathrm{O}_{\mathrm{o}}$ (165 examples) are less; there is no example of $\mathrm{O}_{\mathrm{s}}$. The data show that the appearance frequency of object semantic roles from high to low shows the following sequence: $\mathrm{O}_{a}>\mathrm{O}_{\mathrm{o}}>\mathrm{O}_{\mathrm{s}}$. The $\mathrm{O}_{\mathrm{o}} \mathrm{s}$ perhaps are the prototype of objects in the oracle bone inscriptions, but seen from the quantity scales, the $\mathrm{O}_{\mathrm{a}} \mathrm{s}$ undoubtedly are typical in objects of oracle bone inscriptions. The examples can be seen in $\$ 4.2$.

In a sense, the complicating of sentences in oracle bone inscriptions means that the

\footnotetext{
(1) The objects that sacrificial verbs carry have the patient, cause, tool, target and place, etc. (Zheng Ji'e, 2007:51). The latter four terms are all the $\mathrm{O}_{\mathrm{a}} \mathrm{s}$.
} 


\section{On the Modeling and Development of Verb-object Construction from the Oracle Bone Inscriptions to Jinwen Shangshu}

quantity of objects increases. The poly-object constructions have the double objects, and also have the three objects; besides the double-object constructions expressing transfer (such as the first group), there're the non-transfer double-object constructions that the $\mathrm{O}_{\mathrm{a}} \mathrm{s}$ join in (such as the second group) and the three-object phenomena.

The first group

$$
\begin{gathered}
\text { 【V, } \mathrm{O}_{\mathrm{o}}, \mathrm{O}_{\mathrm{o}} 】 \\
\left(\boldsymbol{V}, \boldsymbol{O}_{\text {dative }}, \boldsymbol{O}_{\text {patient }}\right)
\end{gathered}
$$

(99) 易

$\begin{array}{lll}\text { yi } & \text { Long } & \text { bing } \\ \text { give } & \text { NN } & \text { weapon }\end{array}$

'to give Long the weapons'

$$
\begin{array}{cll}
\left(\boldsymbol{V}, \boldsymbol{O}_{\text {dative }}, \boldsymbol{O}_{\text {result }}\right) & \\
\text { (100) } \text { 作 } & \text { 山 } & \text { 灾 } \\
\text { zuo } & \text { Shan } & \text { zai } \\
\text { make } & \text { PeN } & \text { disaster }
\end{array}
$$

'to make the disaster and give this disaster to Shan'

( $\left.\boldsymbol{V}_{\text {including the patient, }}, \boldsymbol{O}_{\text {associated role }}, \boldsymbol{O}_{\text {dative }}\right)$
$\begin{array}{lll}\text { (101) 穑 } & \text { 我 } & \text { 旅 } \\ \text { se } & \text { wo } & \text { lü } \\ \text { provide the foodstuffs } & \text { me } & \text { army } \\ \text { 'to provide the foodstuffs to the army for me' }\end{array}$

The second group

$$
\begin{aligned}
& \text { 【 } \mathrm{V}, \mathrm{O}_{\mathrm{o}}, \mathrm{O}_{\mathrm{a}} 】 \\
& \left(\boldsymbol{V}, \boldsymbol{O}_{\text {result }}, \boldsymbol{O}_{\text {place }}\right) \\
& \text { (102) 作邑夻 } \\
& \text { zuo yi Cai } \\
& \text { build city PIN } \\
& \text { 'to build the city in Cai' }
\end{aligned}
$$

$$
\text { 【 } \mathrm{V}, \mathrm{O}_{\mathrm{a}}, \mathrm{O}_{\mathrm{a}} \text { 】 }
$$$$
\left(\boldsymbol{V}, \boldsymbol{O}_{\text {tool }}, \boldsymbol{O}_{\text {place }}\right)
$$

$\begin{array}{cll}\text { (103) 卯 } & \text { 羍 } & \text { 掝 } \\ \text { mao } & \text { yang } & \text { Wo } \\ \text { SN } & \text { captive goats } & \text { PIN }\end{array}$

'to sacrifice by mao with captive goats in Wo'

$【 \mathrm{O}_{\mathrm{a}}, \mathrm{V}, \mathrm{O}_{\mathrm{o}} 】$

$$
\left(O_{\text {associated role }}, V_{\text {including the patient }}, O_{\text {dative }}\right)
$$

(104) 我穑 旅




\section{Ma Qinghua \& Li Weizheng}

$\begin{array}{lll}\text { wo } & \text { se } & \text { lü } \\ \text { me } & \text { provide the foodstuffs } & \text { army }\end{array}$

'to provide the foodstuffs to the army for me'

In all the 203 examples of double-object constructions (V, O, O), (V, $\left.\mathrm{O}_{\mathrm{a}}, \mathrm{O}_{\mathrm{a}}\right)$ has 192 examples, $\left(\mathrm{V}, \mathrm{O}_{\mathrm{o}}, \mathrm{O}_{\mathrm{o}}\right)$ has 10 examples, $\left(\mathrm{V}, \mathrm{O}_{\mathrm{o}}, \mathrm{O}_{\mathrm{a}}\right)$ has 1 example, and in the first two that the additives are purposes is 62 examples altogether; $(\mathrm{O}, \mathrm{O}, \mathrm{V})$, which are all $\left(\mathrm{O}_{\mathrm{a}}, \mathrm{O}_{\mathrm{a}}, \mathrm{V}\right)$, are 3 examples altogether; $(\mathrm{O}, \mathrm{V}, \mathrm{O})$, which are all $\left(\mathrm{O}_{\mathrm{a}}, \mathrm{V}, \mathrm{O}_{\mathrm{o}}\right)$, is 1 example altogether. The three-object constructions only have $(\mathrm{V}, \mathrm{O}, \mathrm{O}, \mathrm{O})$ this one kind of word-order type, which is all $\left(\mathrm{V}, \mathrm{O}_{\mathrm{a}}, \mathrm{O}_{\mathrm{a}}, \mathrm{O}_{\mathrm{a}}\right)$, in which $\left(\mathrm{V}, \mathrm{O}_{\text {purpose }}, \mathrm{O}_{\text {target }}, \mathrm{O}_{\text {tool }}\right)$ has 10 examples, and $(\mathrm{V}$, $\left.\mathrm{O}_{\text {tool }}, \mathrm{O}_{\text {purpose }}, \mathrm{O}_{\text {target }}\right)$ has 2 examples. The data confirm the conclusion that the $\mathrm{O}_{\mathrm{a}} \mathrm{s}$ are the typical objects in oracle bone inscriptions once again.

In double-object constructions, the object-preposing constructions, namely $(\mathrm{O}, \mathrm{O}, \mathrm{V})$ constructions, have 3 examples altogether, in which the unmarked ones have 2 examples. The construction in which the objects are preposed and postposed simultaneously, namely $(\mathrm{O}, \mathrm{V}, \mathrm{O})$ construction, has 1 example altogether, which is the unmarked construction.

The academic circle agrees that in oracle bone inscriptions there're the poly-object constructions that the additive arguments join in (Chen Chusheng, 1991; Zheng Ji'e, 2007:69-92; Zhang Yujin, 2001:199-210; Qi Hangfu, 2015:125-212), but at the same time holds that the three objects in oracle bone inscriptions are only limited in "causal objects", "target objects" (deity names) and "tool objects" (names of sacrificial offerings)" that "sacrificial verbs" carry (Zheng Ji'e, 2007:82; Qi Hangfu, 2015:206). At present, the academic circle not only doesn't deeply recognize the typical status of $\mathrm{O}_{\mathrm{a}} \mathrm{s}$ in Shang language from aspect of lingual system, but also doesn't further think of their formation reason. The reasons that the frequency of $\mathrm{O}_{\mathrm{a}} \mathrm{s}$ in oracle bone inscriptions is so high are as follows:

First, the meaning of some verbs in oracle bone inscriptions doesn't fully absorb the relative meaning of predicate-argument constructions to get the transitive nature, which leads target arguments to high-frequency arguments located in the non-core status. The verbs carrying this kind of arguments usually are limited in the sacrifice verbs, which in sentences can never carry other arguments besides subjects (including the target arguments), such as the following examples:

$\begin{array}{ll}\text { (105) 呼 } & \text { 前 } \\ \text { hu } & \text { qian } \\ \text { give the command } & \text { SN } \\ \text { 'to give the command to sacrifice by qian' } \\ \begin{array}{ll}\text { (106) } \text { 用 } & \text { 伐 } \\ \text { yong } & \text { fa }\end{array}\end{array}$




\section{On the Modeling and Development of Verb-object Construction from the Oracle Bone Inscriptions to Jinwen Shangshu}

$\begin{array}{lc}\text { put into effect } & \text { SN } \\ \text { 'to put into effect sacrificing by fa' } \\ \text { (107) } \text { 为 } & \text { si } \\ \text { wei } & \text { SN } \\ \text { put into effect } & \text { 福 } \\ \text { 'to put into effect sacrificing by si' } \\ \text { (108) 梦 } \\ \text { meng } \\ \text { dream about } & \text { SN } \\ \text { 'to dream about sacrificing by fu' }\end{array}$

The target arguments sometimes can use preposition "于 yu" to introduce something and be used as the adverbials, such as:

$\begin{array}{llll}\text { (109) 占方 } & \text { 于 } & \text { 河 } & \text { 勾 } \\ \text { Gongfang } & \text { yu } & \text { he } & \text { gai } \\ \text { NN } & \text { PT } & \text { river god } & \text { SN }\end{array}$

'to sacrifice the river god by gai because of Gongfang'

In primitive languages, the verbal transitive nature isn't inherently acquired, and the process needs two steps: Firstly the pauses between verbs and nouns are cancelled to form the verb-object constructions. In oracle bone inscriptions some comparatively little relevant residual impressions can be found out. Please make a comparison between (110a) and (110b). (110b) is the grammatical reconstruction caused by the cancelling of the pauses, which is the crux to revealing the formation of verb-object constructions. Secondly verbs that fully absorb the construction relation of predicate-argument get the dominating meanings.

$$
\begin{array}{rll}
\text { (110) a.卯, } & \text { 惟 } & \text { 羊? } \\
\text { mao } & \text { wei } & \text { yang } \\
\text { SN } & \text { EM } & \text { goat }
\end{array}
$$

'to sacrifice by mao, and are the sacrificial offering goats'

$$
\begin{array}{cl}
\text { b. 卯 } & \text { 羊? } \\
\text { mao } & \text { yang } \\
\text { SN } & \text { goat }
\end{array}
$$

'Are the goats used to sacrifice by mao?'

Second, the marking level in oracle bone inscriptions is low. The oracle bone inscriptions are short of the comparatively complete system of the marks of arguments (prepositions), and only 4 words (i.e. “于 ${ }_{\mathrm{yu}}$, 自 $\mathrm{zi}$, 在 ${ }_{z a i}$, 从 cong”) are recognized as perpositions in academic circle (Qi Hangfu, 2015:215), while some scholars hold that there're only 2 words (i.e. “于yu” and “自zi”) are prepositions. The functions and 
distributions of "于 yu" are: target-argument mark (68\%)>place-argument mark (18\%)> time-argument mark (9\%) > verb (5\%)(Yang Fengbin, 2003:278-337). “自” expresses the sources (Zhang Yujin, 2001:82), and is ablative mark. Because of being short of the marking methods, when the additive arguments are so many that they can't be expressed by syntactic additive components (such as adverbials and complements), they can only be expressed by syntactic core components, and on the basis of non-symmetric relation of subjects and objects, preferentially select the objects, not the subjects.

After adding the marks, the additive arguments become the additive syntactic components (such as complements or adverbials). Even though some additive arguments have had the marking conditions, marks are not usually compulsory. However, sometimes having the marks or not also can be in relation to distinguishing the meanings or the limit of verbal meanings. Please make a comparison:

【 The target argument 】

\begin{tabular}{|c|c|c|c|c|c|c|}
\hline \multirow{2}{*}{\multicolumn{2}{|c|}{$\begin{array}{l}\text { (111) 祝 } \\
\text { zhu }\end{array}$}} & \multicolumn{5}{|l|}{ 父 } \\
\hline & & \multicolumn{5}{|l|}{$\mathrm{Fu}$} \\
\hline & SN & \multicolumn{5}{|l|}{$\mathrm{DN}$} \\
\hline \multicolumn{7}{|c|}{ 'to sacrifice Fu by zhu' } \\
\hline (112) & 王 & 勿 & 祝 & 于 & 四 & 父 \\
\hline & wang & wu & zhu & $y u$ & si & $\mathrm{Fu}$ \\
\hline & king & not & SN & PT & four & $\mathrm{DN}$ \\
\hline
\end{tabular}

'The King won't sacrifice four Fu by zhu'
(113) 御父乙
yu Fuyi
SN DN

'to sacrifice Fuyi by yu'

$\begin{array}{rll}\text { (114) 御 } & \text { 于 } & \text { 父辛 } \\ \mathrm{yu} & y u & \text { Fuxin } \\ \mathrm{SN} & \mathrm{PT} & \mathrm{DN}\end{array}$

'to sacrifice Fuxin by yu'

【 The place argument 】

(115) 来启

lai Qi

\footnotetext{
(1) The divergence mainly attributes to the judgements for degrees of grammaticalization, and the judgements for degrees of grammaticalization about prepositions must be put in complex constructions appearing simultaneously with predicates and the relation of non-continuous predicate. However, it is not easy to exclude the relation of continuous predicate, because even the possible prepositions, their grammaticalization isn't also fully mature, and they still have the certain verbal nature.
} 


\section{On the Modeling and Development of Verb-object Construction from} the Oracle Bone Inscriptions to Jinwen Shangshu

\section{go to PIN}

'to go to Qi'

(116) 方

fang

$\begin{array}{llll}\text { 其 } & \text { 来 } & \text { 于 } & \text { 沚 } \\ \text { qi } & \text { lai } & y u & \text { Zhi } \\ \text { EM } & \text { go to } & \text { PP } & \text { PIN }\end{array}$

army in some country

EM go to

'The army in some country goes to Zhi exactly'

(117) 往

wang Zhi
go to PIN
'to go to Zhi'

(118)

$\begin{array}{lllll}\text { 呼 } & \text { 师般 } & \text { 往 } & \text { 于 } & \text { 微 } \\ \text { hu } & \text { Shiban } & \text { wang } & y u & \text { Wei } \\ \text { give the command } & \text { PeN } & \text { go to } & \text { PP } & \text { PIN }\end{array}$

'to give the command that Shiban goes to Wei'

【 The ablative 】
(119) 出京
chu Jing
leave PIN
'to leave Jing'

$\begin{array}{clll}\text { (120) 王 } & \text { 步 } & \text { 自 } & \text { 商 } \\ \text { wang } & \text { bu } & \text { zi } & \text { Shang } \\ \text { king } & \text { walk } & \text { from } & \text { country name }\end{array}$

'The king walks from Shang'

【 The comitative 】

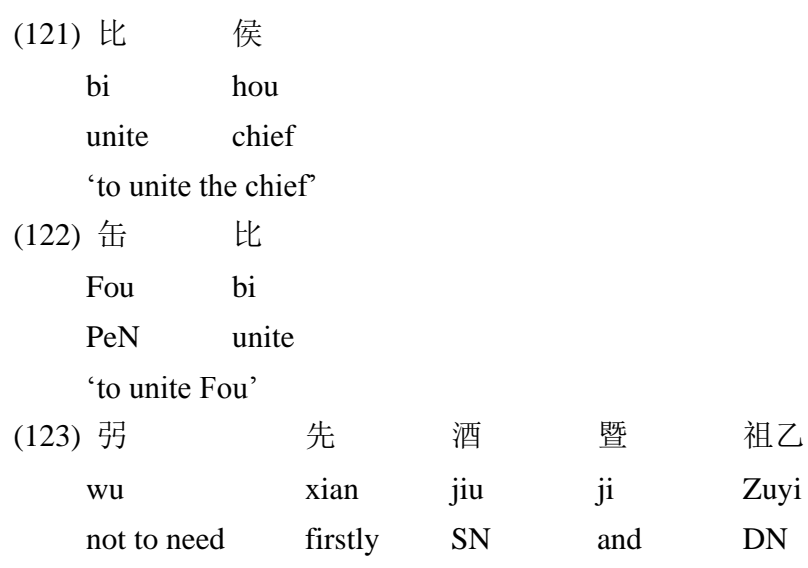

'Not to need to sacrifice some god and Zuyi by jiu firstly'

The oracle bone inscriptions are also short of the comparatively complete system of 


\section{Ma Qinghua \& Li Weizheng}

logical marks (conjunctions). The conjunctions mainly express the co-ordnate relation, and fewly express the progressive relation and hypothesis relation (Jiang Baochan, 1982; Zhao Cheng, 1986; Zhang Yujin, 2001:88), but do not find the causes/purpose conjunctions. Because the logical relations of reasons/purposes do not have the corresponding marks to be used, they only can be located in the syntactic relations to be expressed by objects in core components. For example:

$$
\begin{aligned}
& \left(V,\left(V,\left(V, O_{\text {concerned role Vassociated role }}\right) \text { o: purpose/cause }\right)\right. \\
& \text { (124) 克兴有疾 } \\
& \text { ke } \quad \text { xing you ji } \\
& \text { can } \mathrm{SN} \text { be ill }
\end{aligned}
$$

Third, the suitable scopes of nominal adverbials in oracle bone inscriptions are small, and the single noun can't act as the complement. In oracle bone inscriptions the nouns acting as the fixed adverbials are mainly limited to the time nouns, which become the objects if postposed, and the nouns can't act as the complements (Zhang Yujin, 2001:162-163, 171,177).

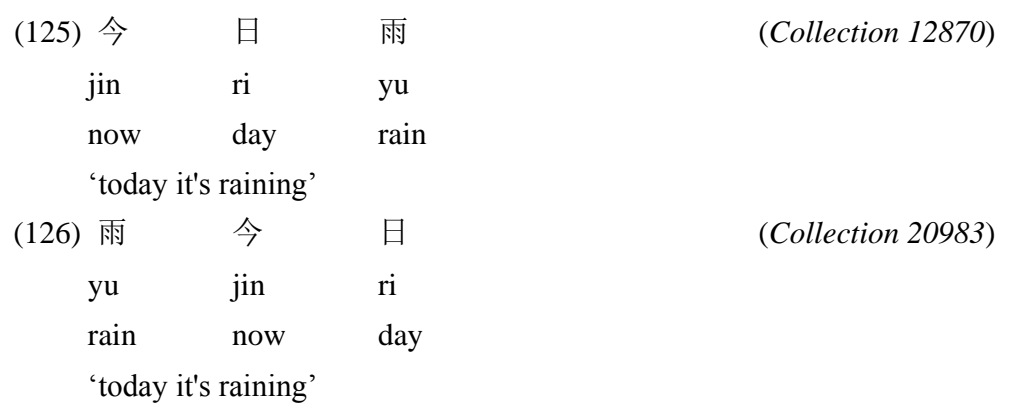

Li Xi (2004:190) holds that if the nouns after verbs can be added with case marks, they can be seen as the complements. For example, “西(xi, west)" in (127) can be seen as omitting the preposition “于”, so it becomes the complement.

\begin{tabular}{llll} 
(127) 惠王 & 自 & 往 & 西 \\
Huiwang & zi & wang & xi \\
PeN & himself & go to & west \\
\multicolumn{4}{l}{ 'Huiwang himself goes to the west' }
\end{tabular}

This viewpoint is wrong. Having or not having the ability or condition to carry the marks and actually carrying or not carrying the marks are two different situations.

The $\mathrm{O}_{a}$ still exists in Xizhou Chinese as (128)-(131)(Zhang Yujin, 2004:232-234, 130-175).

$\begin{array}{llll}\text { (128) [place object] } & \text { 王 } & \text { 女(如) } & \text { 上侯 } \\ & \text { wang } & \text { ru } & \text { Shanghou }\end{array}$


On the Modeling and Development of Verb-object Construction from the Oracle Bone Inscriptions to Jinwen Shangshu

king go to PIN

'The king goes to Shanghou.'

(129) [target object] 利

利

li she da chuan

be advantageous to wade big river

'It's advantageous to wade the big rivers'

(130) [tool object] 伯氏 吹 埙

Boshi chui xun

PeN blow an ancient egg-shaped, holed wind instrument

'Boshi blows the xun.'

$\begin{array}{llllll}\text { (131) [purpose object] } & \text { 坎坎 } & \text { 鼓 } & \text { 我, 蹲蹲 } & \text { 舞 我 } \\ \text { kankan } & \text { gu } & \text { wo cuncun } & \text { wu wo } \\ & \text { sound of drumbeat } & \text { beat the drums } & \text { me dancing looks dance me } \\ & \text { 'to beat the drums kankan for me, to dance cuncun for me' }\end{array}$

The non-compulsive nature of marks of additive arguments and relevant phenomenon of non-transfer poly-objects also still exist. However, because the prepositions are already comparatively complete, some of them already can be seen as the result of omitting the prepositions. According to Pan Yukun (2005:115), in Xizhou there're also the double objects caused by omitting the prepositions, such as (132)-(135) in Xizhou bronze inscriptions.

$\begin{array}{cllllll}\text { (132) 我 } & \text { 既 } & \text { 赎 } & \text { 汝 } & \text { 五 } & \text { 夫 } & \text { 效父 } \\ \text { wo } & \mathrm{ji} & \text { shu } & \mathrm{ru} & \text { wu } & \mathrm{fu} & \text { Xiaofu } \\ \mathrm{I} & \text { already } & \text { redeem } & \text { you } & \text { five } & \text { people } & \text { PeN }\end{array}$

'I have already redeemed you five people with Xiaofu.'

$\begin{array}{clllllll}\text { (133) 我 } & \text { 既 } & \text { 赎 } & \text { 汝 } & \text { 五 } & \text { 夫 } & \text { 以 } & \text { 效父 } \\ \text { wo } & \mathrm{ji} & \mathrm{shu} & \mathrm{ru} & \mathrm{wu} & \mathrm{fu} & y i & \text { Xiaofu } \\ \mathrm{I} & \text { already } & \text { redeem } & \text { you } & \text { five } & \text { people } & \text { with } & \text { PeN }\end{array}$

'I have already redeemed you five people with Xiaofu.'

$\begin{array}{lllll}\text { (134) } \begin{array}{l}\text { 扰 } \\ \text { rao }\end{array} \text { nai } & \text { xiao } & \text { da } & \text { 事 } \\ \text { bother } & \text { you } & \text { small } & \text { big } & \text { thing } \\ \text { 'to bother you with small and big things' } & \end{array}$

$\begin{array}{clllll}\text { (135) 扰 } & \text { 乃 } & \text { 以 } & \text { 小 } & \text { 大 } & \text { 事 } \\ \text { rao } & \text { nai } & y i & \text { xiao } & \text { da } & \text { shi } \\ \text { bother } & \text { you } & \text { with } & \text { small } & \text { big } & \text { thing }\end{array}$

'to bother you with small and big things' 


\section{Ma Qinghua \& Li Weizheng}

However, the application scope of nominal adverbials extends to the relations of directions and manners besides time relation (Guan Xiechu, 1981:92-104; Zhang Yujin, 2004:250-251). The system of argument marks (prepositions) and system of logical marks (conjunctions) are already basically complete (Zhang Yujin, 2004:232-234, 130-175). Guan Xiechu holds that the objects only include the $\mathrm{O}_{o} \mathrm{~s}$, which have 1986 examples altogether, and the objects governed by prepositions. He puts all $\mathrm{O}_{\mathrm{a}} \mathrm{s}$ into complements, and has found out that examples of this kind, which are only 10 examples (Guan Xiechu, 1981:88, 154, 158), are rare in Xizhou bronze inscriptions. So in Xizhou Chinese the objects have substituted for the typical status of additives in objects.

The use of words and word quantities of prepositions introducing the arguments of times, places, targets, tools, methods, conditions, evidences and causes, etc. and purpose conjunctions expressing the logical relations, etc. (Qian Zongwu, 2004:178, 231, 265, 404-423) in Jinwen Shangshu are all roughly the same as those in Xizhou bronze inscriptions, which shows that the relevant mark system is already comparatively complete, and roughly stable. All the double-object sentences in modern-scrip Shangshu that Qian Zongwu (2004:178, 231, 265, 404-423) investigates are all the transfer sentences, and from this it can be seen that the typical status of additives in objects has declined. The declination of $\mathrm{O}_{\mathrm{a}} \mathrm{s}$ has necessary relation with being complete of marks of additive argumments (namely adequate intervention of the means of function-words), extension of applicable scopes of nominal adverbials and attainment of verbal transitive meanings.

However, the word orders of double-object constructions in Xizhou bronze inscriptions and Jinwen Shangshu still have the imprints of comparatively low modeling level. According to statistics for 312 bronze wares of Shen Chunhui (1936), in transfer double-object constructions in Xizhou bronze inscriptions, " $\left(\mathrm{V}, \mathrm{O}_{\text {indirect }}, \mathrm{O}_{\text {direct }}\right)$ " are 119 examples altogether, " $\left(\mathrm{O}_{\text {indirect, }} \mathrm{V}, \mathrm{O}\right.$ direct $)$ " are 7 examples altogether, and " $\left(\mathrm{O}_{\text {direct }}, \mathrm{V}, \mathrm{O}\right.$ indirect)" is 1 example, which as a whole shows the word-order tendencies that "the verbs are before objects" and "the indirect objects are before objects", but there's also the exceptional phenomenon that the objects are preposed before verbs and postposed after verbs simultaneously, which inherits from the unusual word orders of double-object constructions in oracle bone inscriptions (see §4.2). Similarly, the basic constructions of double-object constructions in Jinwen Shangshu are ( $\mathrm{V}, \mathrm{O}$ indirect, $\left.\mathrm{O}_{\text {direct }}\right)$, which have 25 examples altogether, but there're also occasional examples that the objects are preposed before verbs and postposed after verbs simultaneously, such as the following examples (Qian Zongwu, 2004:408, 417):

$\begin{array}{rlllll}\text { (136) } \text { 中 } & \text { 邦 } & \text { 锡 } & \text { 土 } & \text { 姓 } & \text { (虞夏书) } \\ \text { zhong } & \text { bang } & \text { ci } & \text { tu } & \text { xing } & \text { (Yuxiashu) } \\ \text { central } & \text { country } & \text { give } & \text { earth } & \text { surname } & \end{array}$




\section{On the Modeling and Development of Verb-object Construction from the Oracle Bone Inscriptions to Jinwen Shangshu}

\begin{tabular}{|c|c|c|c|c|}
\hline \multicolumn{5}{|c|}{ 'The central country gives the earth and surnames' } \\
\hline (137) 禹 & 锡 & 玄 & 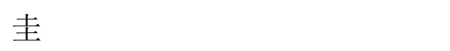 & (虞夏书) \\
\hline yu & ci & xuan & gui & (Yuxiashu) \\
\hline $\mathrm{Yu}$ & give & black & an elongated pointed tablet of jade & \\
\hline
\end{tabular}

According to the conclusion drawn by the two scholars Shen Chunhui and Qian Zongwu that all the arguments of transfer double-object constructions in Xizhou bronze inscriptions and Jinwen Shangshu, all can use the mark condition (prepositions “以yi" “于 yu”) to become the adverbials or complements, so as to transform the double-object constructions into single-object constructions.

\section{Conclusion}

The verb-object constructions in oracle bone inscriptions have both the verb-object and object-verb constructions, and from three perspectives of frequency, mark and nesting, etc., the object postposing is their basic word-order tendency. The different preposing methods of objects in oracle bone inscriptions come from different reasons. The marked preposing is mainly attributed to the need of emphases. Firstly, because the strength of lingual force of marked preposing is obviously higher than the unmarked preposing. Secondly, because the object preposing about "其q", whose formation experiences the adaptation of many links, is to take the anaphora and emphases of "其q" as the first impetus. The addressing and demonstrative functions of "其qi", which continues in following Chinese, have existed in oracle bone inscriptions; the modal meaning of "其q" in oracle bone inscriptions is "imperative" or "will", it also express "speculate" and "rhetorical question" in pre-Qin, and these meanings all derive from the pronoun meanings. In addition, the adherence nature of "其qi" also makes the relation between it and predicate construction as succedent tight, then breaks the anaphora relation between "其 ${ }_{\mathrm{qi}}$ " and $\mathrm{O}$, and the reanalysis appears in " $\mathrm{O}$ 其 ${ }_{\mathrm{qi}} \mathrm{V}$ " construction, namely " $\mathrm{O}$ 其 $_{\mathrm{q}} \mathrm{i} / \mathrm{V} \rightarrow \mathrm{O} /$ 其 $_{\mathrm{qi}} \mathrm{V}$ ". By analogy, it directly leads to the new important grammatical principle: in negative sentences pronoun objects need the preposing. In oracle bone inscriptions, the object postposing is usual, but in negative sentences, pronouns “我(wo, 'I, me'), 余(yu, 'I, me'), 尔(er,'you')”, etc., usually acting as the objects are preposed, and seldom postposed. This construction, in which the pronouns are used after negative words, is followed in Xizhou Chinese and Shangshu, and modeling level is enhanced in development, which shows: 1. the scope of appropriate pronouns extends; 2. the principle is stricter. To some extent, the unmarked preposing is attributable to the comparatively low level of syntactic modeling of primitive languages, which show in background features including the two aspects, namely shallow nesting ability and low word-order modeling level. 


\section{Ma Qinghua \& Li Weizheng}

$\begin{array}{ll}\text { Symbols and abbreviations } \\ \text { An } & \text { Anaphora } \\ \text { AP } & \text { Attributive Particle } \\ \text { DN } & \text { Deity Name } \\ \text { DP } & \text { Demonstrative Pronoun } \\ \text { EM } & \text { Emphasis } \\ \text { FS } & \text { Filled Syllable } \\ \text { Interj } & \text { Interjection } \\ \text { NN } & \text { National Name } \\ \mathrm{O}_{\mathrm{a}} & \text { Object components acted by additive arguments } \\ \mathrm{O}_{\mathrm{o}} & \text { Object components acted by object arguments } \\ \text { OP } & \text { mark of Object Preposing } \\ \mathrm{O}_{\mathrm{s}} & \text { Object components acted by subject arguments } \\ \text { PeN } & \text { People Name } \\ \text { PeP } & \text { Perfective Aspectual Particle } \\ \text { PIN } & \text { Place Name } \\ \text { PoN } & \text { Position Name } \\ \text { PP } & \text { Preposition Introducing the Place } \\ \text { PT } & \text { Preposition Introducing the Target } \\ \text { Q } & \text { Quantifier } \\ \text { SN } & \text { Sacrifice Name }\end{array}$

\section{References}

Chen Chusheng. 1991. On the Expression Methods of Poly-target Constructions of Verbs in pre-Qin Chinese [J], Studies of the Chinese Language, (2).

Guan Xiechu. 1981. The Grammatical Research of Xizhou Bronze Inscriptions [M]. Beijing: The Commerial Press.

Harrison, S. P. \& S. Albert. 1977. Mokilese-English Dictionary [M]. Honolulu: The University Press of Hawaii.

Jiang Baochang. 1982. The Tentative Analysis of Function Words in Oracle bone inscriptions [A], in The Research of Chinese in pre-Qin [C], Jinan: Shandong Education Press.

Li Xi. 2004. The Grammar of Oracle bone inscriptions [M]. Xi'an: Shanxi Normal University Press.

Ma Qinghua. 1993. The Semantic Constructions in the Sentences [J], Nanjing Normal University Journal, (4).

Ma Qinghua. 2006. The Multidimensional Research of Semantics [M]. Beijing: The Chinese Language Press.

Ma Qinghua. 2012. The Linguistic Problems under System Principle [M]. Shanghai: Shanghai People Press.

Ma Qinghua. 2014a. The Self-propagating of Syntactic System in the Principle of Adaptation [J], Linguistic Research, (1).

Ma Qinghua. 2014b. The Integration of Grammatical Structure under the Principle of Common Theme-Seeking [J], Shanxi University Journal, (4).

Ma Qinghua, Fang Guangzhu, Han Xiao and Zhu Hong. 2017. The Polysynthetic Languages: the Extreme of Morphological Complexity [M]. Beijing: China Social Scinence Press.

Pan Yukun. 2005. The Word-order Research of Xizhou Bronze Inscriptions [M]. Shanghai: Shanghai Normal University Press.

Qi Hangfu. 2015. The Word-order Research of Objects in Oracle bone inscriptions [M]. Shanghai: Zhongxi Press.

Qian Zongwu. 2004. On the Grammatical Research of Jinwen Shangshu [M]. Beijing: The Commercial 


\section{On the Modeling and Development of Verb-object Construction from the Oracle Bone Inscriptions to Jinwen Shangshu}

Press.

Qian Zongwu. 2017. On Syntactic Characteristics of Jinwen Shangshu [J]. Macrolinguistics, (6).

Shen Chunhui. 1936. On the Double-object Constructions in Zhou Bronze Inscriptions [J], Yanjing Journal, (20).

Shi Cunzhi. 1986. The Outline of History of Chinese Grammar [M]. Shanghai: East China Normal University Press.

Sohn, H. M. \& A. F Tawerilmang. 1976. Woleaian-English Dictionary [M]. Honolulu: The University Press of Hawaii.

Wang Danian. 1994. The Object-preposition Constructions in Shangshu [J], Research in Ancient Chinese Language, (1).

Xu Zhongshu. 2006. The Dictionary of Oracle bone inscriptions [M]. Chengdu: Sichuan Dictionary Press.

Yang Fengbin. 2003. On the parts of speech in Oracle bone inscriptions [M]. Guangzhou: Huacheng Press.

Yao Xiaosui and Xiao Ding. 1989. The Classified Compilation of Oracle bone inscriptions [M]. Beijing: Zhonghua Book Company.

Zhang Yujin. 2001. On the Meaning of "其 qi" in Oracle bone inscriptions and Bronze Inscriptions [J], Yindu Journal, (1).

Zhang Yujin. 2001. A Grammar of Oracle bone inscriptions [M]. Shanghai: Xuelin Press.

Zhang Yujin. 2004. A Grammar of Xizhou Chinese [M]. Beijing: Commercial Press.

Zhang Yujin. 2006. The Research of Pronoun in Xizhou Chinese [M]. Beijing: Zhonghua Book Company.

Zhao Cheng. 1986. The Research of Function Words in Oracle bone inscriptions [A], The Research of Ancient Characters (15) [C], Beijing: Zhonghua Book Company.

Zheng Ji'e. 2007. The lingual Research of Oracle bone inscriptions Expressing the Sacrifice [M]. Chendu: Bashu Press.

Zhou Bingjun. 1984. The Simple Explanation of Shangshu [M]. Changsha: Yuelu Press.

Zhu Dexi. 1986. The Parallel Principle in Transform Analysis [J], Studies of the Chinese Language, (2). 